\title{
Public or perish? From founding to initial public offering
}

\author{
Yuji Honjo $^{1}$
}

Received: 17 April 2019 / Accepted: 5 April 2020 / Published online: 20 April 2020

(C) The Author(s) 2020

\begin{abstract}
We examine the factors affecting the time to initial public offering (IPO), using a sample of more than 10,000 start-up firms in Japan. We provide evidence that startup firms engaging in innovative and uncertain businesses are more likely to go public earlier than other firms. The results also reveal that start-up firms that rely on equity financing at founding are more likely to go public earlier than others. Moreover, we find that start-up firms in highly valued industries are more likely to go public earlier than in other industries and that the likelihood of an IPO among start-up firms depends on market conditions.
\end{abstract}

Keywords Initial public offering $\cdot$ Start-up $\cdot$ Survival analysis

JEL Classification $\mathrm{G} 30 \cdot \mathrm{L} 26 \cdot \mathrm{M} 13 \cdot \mathrm{O} 32$

\section{Introduction}

An initial public offering (IPO) is not a stage that all firms eventually reach, but it is a critical stage in the growth process. While some entrepreneurs pursue the possibility of access to public equity markets through an IPO, most firms remain privately held. Essentially, it is not easy for start-up firms to go public within a short period of time. Nevertheless, high-tech start-ups with uncertain businesses-for example, biotechnology start-ups for drug discovery-often seek access to public equity markets through an IPO, despite their lack of business history and track record. Such firms require massive research and development $(R \& D)$ expenditures and often demand funds for R\&D projects. Going public within a short period allows high-tech startups to secure funds for R\&D projects. Although IPO firms (publicly listed firms) represent only a small proportion of the entire population of start-up firms, they are

Yuji Honjo

yhonjo@tamacc.chuo-u.ac.jp

1 Faculty of Commerce, Chuo University, 742-1 Higashinakano, Hachioji, Tokyo 192-0393, Japan 
expected to promote economic growth because of their growth potential. Some IPO firms indeed achieve rapid growth by accessing public equity markets.

It has often been argued in the literature that start-up firms play a significant role in economic growth (e.g., Audretsch 1995; Audretsch and Acs 2003). The emergence of start-up firms that achieve rapid growth-sometimes called "gazelles"has been the focus of much public policy discussion because such firms are essential contributors to future economic growth (e.g., Henrekson and Johansson 2010; Koski and Pajarinen 2013). Not surprisingly, young IPO firms outperform others by a wide margin, and they are expected to boost economic growth through innovation and job creation. These firms can also provide early-stage shareholders with high capital gains by going public, which often attracts venture capitalists, despite the high risks involved. Thus, the creation of young IPO firms has become one of the most critical issues, especially in stagnating developed economies. Nevertheless, little attention has been paid to which start-up firms achieve IPOs sooner. Whereas an IPO is wellknown as a typical sellout strategy for early-stage shareholders, the determinants of an IPO among start-up firms have not been entirely clear in the literature.

This study explores the IPOs of start-up firms. We examine the factors affecting the time to IPO, using a sample of more than 10,000 start-up firms (joint-stock companies) in Japan. Specifically, we examine whether start-up firms that engage in innovative and uncertain businesses, which are measured by R\&D expenditures and capital flexibility, are more likely to go public earlier than other firms. We provide evidence that the time to IPO depends on the type of start-ups at the time of founding (incorporating) and that start-up firms engaging in innovative and uncertain businesses are more likely to go public earlier than other firms, suggesting that such uncertainty may result in hasty IPOs. The results also reveal that start-up firms that rely on equity financing at founding are more likely to go public earlier than others. We provide rigorous evidence on the effect of initial capital structure on the time to IPO while considering competing risks, such as firm exits due to business failure. ${ }^{1}$ Moreover, we find that start-up firms in highly valued industries are more likely to go public earlier than in other industries and that the likelihood of an IPO among start-up firms depends on market conditions.

This study contributes to providing evidence on whether start-up firms that engage in innovative and uncertain businesses tend to access public equity markets. Some studies have emphasized the importance of equity financing for R\&D investment (e.g., Carpenter and Petersen 2002a; Hall 2002; Colombo and Grilli 2007). Innovative and risky start-ups, which are devoted to innovative and uncertain projects, tend to face difficulties in raising debt financing because banks are reluctant to provide funds to such firms. Several countries, including some European countries and Japan, have introduced "junior stock markets" (also called "second-tier stock markets" or "new stock markets") since the mid and late 1990s, in order to provide

\footnotetext{
1 While "exit" has often been used to a shareholder's sellout in the literature on corporate finance, it has traditionally indicated a firm's exit from the market in the literature on industrial organization (e.g., Harhoff et al. 1998). In this study, we use "firm exit" or "exit" as the latter; hence, IPO is not included in firm exit.
} 
equity financing for young and innovative firms with growth potential. Indeed, IPOs in these markets have accounted for a large portion of IPOs during recent years. Nevertheless, little is known about whether the introduction of junior stock markets helps innovative start-ups conduct early IPOs. The findings of this study suggest that innovative and risky start-ups tend to go public within a short period of time, which would support the view that junior stock markets play a role in providing equity capital to these start-ups. Moreover, we examine the time from the founding of firms to their IPOs, while little attention has been paid in the literature to the IPOs of startup firms (e.g., Pagano et al. 1998; De Jong et al. 2012). By doing so, we provide new insights into the determinants of IPOs, such as capital structure and firm size, from the perspective of the firm's growth cycle. We present different results for their determinants from previous studies and emphasize the importance of path dependence of capital structure. Furthermore, we pay attention to firm exits due to business failure, other than IPOs, because innovative and risky start-ups have a higher probability of bankruptcy. This study provides evidence that risky start-ups, measured by capital flexibility, are more likely to fail within a short period. Our findings suggest that such firms are more likely to not only go public sooner but also disappear, that is, "public or perish."

The remainder of this paper is organized as follows. The following section introduces the research background, including the literature review. In the third section, we discuss the hypothesis development on the determinants of IPOs. The fourth and fifth sections explain the method and data used, respectively. The sixth section presents the estimation results. Finally, we present some concluding remarks.

\section{Literature review and research background}

\subsection{Financing of innovative and uncertain businesses}

Innovation produced by start-up firms affects the existing sources of market power by spurring the "gale of creative destruction," as described by Joseph Schumpeter (Gans et al. 2002: p. 571). According to the replacement effect, young and innovative firms, especially high-tech start-ups, have a stronger incentive for innovation than existing firms. Such firms play a pivotal role in promoting innovation as a vehicle for transferring and capitalizing knowledge (Audretsch et al. 2008; Colombo et al. 2016; Block et al. 2018). To promote the emergence of young and innovative firms with growth potential, policymakers have focused on how these firms secure financing for risky $R \& D$ projects.

Not surprisingly, start-up firms do not always obtain the required funds at founding, even if they require investment to maintain their businesses. These firms sometimes encounter financial constraints. Generally, external suppliers of capital, such as banks, have less information about firms' projects unlike the firms themselves, and such information is costly to obtain (Binks et al. 1992; Binks and Ennew 1996). In particular, uncertainty and information asymmetries between entrepreneurs and external suppliers of capital are more severe for start-up firms due to their lack of operating history and track record (Honjo et al. 2014). Such uncertainty and 
information asymmetries prevent start-up firms from obtaining bank loans because the cost of capital increases with information asymmetries, in addition to the uncertainty in business prospects. Start-up firms are more likely to encounter costs arising from uncertainty and information asymmetries.

Among start-up firms, high-tech start-ups are more likely to require external financing for massive R\&D expenditures. However, information asymmetries between high-tech start-ups and external suppliers of capital, such as banks, become more severe. Indeed, banks hesitate to provide additional funds to high-tech startups because debt financing increases the probability of bankruptcy. Previous studies have emphasized that moral hazard and adverse selection problems due to information asymmetries hinder the external financing of highly risky businesses, including high-tech start-ups (e.g., Arrow 1962; Himmelberg and Petersen 1994; Carpenter and Petersen 2002a). Banks are reluctant to lend money to high-tech start-ups, primarily because of the difficulty involved in evaluating new businesses and technologies. The returns of $R \& D$ projects are highly uncertain, and their quality is difficult to evaluate (Müller and Zimmermann 2009). R\&D investment has a higher probability of becoming a sunk cost, and such firms have few tangible assets to provide sufficient collateral (Kamien and Schwartz 1978; Carpenter and Petersen 2002b; Hall 2002). Start-up firms that engage in $R \& D$ projects are more likely to face higher costs arising from uncertainty and information asymmetries due to the difficulty involved in evaluating new businesses and technologies (Honjo et al. 2014). These firms may encounter financial constraints for R\&D investment because they have not accumulated profits or steady cash flow from their R\&D projects (Czarnitzki and Hottenrott 2011). R\&D investment is considered a firm risk due to the uncertainty inherent in such explorative investment (Arrfelt et al. 2018).

Some studies have argued that new equity has many advantages over debt for financing high-tech investment (e.g., Carpenter and Petersen 2002a; Hall 2002; Colombo and Grilli 2007). As discussed above, innovative and risky start-ups tend to face difficulties in raising debt financing, such as bank loans, even though they require capital to continue their projects. Since many high-tech start-ups do not generate cash flow within a short period of time, debt-financing interest payments often become a burden on them. To continue their projects, including R\&D, hightech start-ups are more likely to rely on equity financing, rather than debt financing. Moreover, early-stage shareholders, including entrepreneurs, have an incentive to go public, which could secure them the opportunity to sell their highly risky shares. Furthermore, for high-tech start-ups, an IPO is often a means to pursue investment and acquire participation in other firms (Vismara 2014). It is conceivable that startup firms devoted to innovative and uncertain projects tend to seek access to public equity markets.

\subsection{Decision to go public}

An IPO has been considered simply as a stage in the growth process, but the decision to go public is essentially more complex (Pagano et al. 1998). Previous studies have emphasized the benefits of going public: diversification, the possibility of 
equity financing beyond the initial entrepreneurs' limited wealth, less costly access to the capital market, increased liquidity of the firms' share, some outside monitoring, enhanced company image and publicity, motivating management and employees, and cashing in (Zingales 1995; Röell 1996; Pagano et al. 1998). Ritter and Welch (2002) also reviewed the theories and evidence on IPO activity, and identified the life cycle and market-timing theories in the decision to go public. From the viewpoint of the firms, the decision to go public eventually depends on the trade-off between their benefits and costs of going public; that is, firms have an incentive to go public if the expected net benefits from it are larger than the expected net benefits from remaining private. ${ }^{2}$ The benefits of going public may increase with the demand for investment. The opportunity to access public equity markets is particularly appealing for firms with investment opportunities (Pagano et al. 1998). Such firms expect to mitigate financial constraints by acquiring access to equity markets.

While there are many arguments for going public, some empirical studies directly estimate the determinants of IPOs. Previous studies found from the data on European and US firms that firm characteristics, such as firm size and age, affect the decision to go public (e.g., Pagano et al. 1998; Chemmanur et al. 2010; Aslan and Kumar 2011; De Jong et al. 2012; Cattaneo et al. 2015). ${ }^{3}$ However, although Ritter and Welch (2002) emphasized the viewpoint on the life cycle of firms, few studies have focused on IPOs in the growth process of firms. Even though previous studies have provided some evidence on the determinants of IPOs, their results may be due to survivor bias. Specifically, firms that are privately held for a long period of time are always included in the sample, while young and small firms tend to be excluded because these firms are more likely to disappear due to bankruptcy or liquidation during the start-up stage. Thus, we should pay more attention to the competing events prior to an IPO, especially when investigating the IPOs of start-up firms. Moreover, for example, if a positive effect of firm size on the likelihood of an IPO is found in the analysis, the results may be due to causality problems because firms enlarge their sizes to adopt listing requirements to access public equity markets. Accordingly, the majority of these problems in previous studies come from samples regardless of firm age, in addition to the ignorance of the time from founding to going public.

Much attention should be paid to the IPO decision of younger firms, rather than older ones, from the perspective of fostering start-up firms with growth potential. It is conceivable that an IPO is closely related to firm age from the perspective of the financial growth cycle of firms (Berger and Udell 1998). Despite the importance of young IPO firms in boosting economic growth, few studies have examined the IPOs of start-up firms. In addition, according to the perspective of path dependence in financing, initial conditions may continuously dominate post-entry behavior,

\footnotetext{
${ }^{2}$ Going public entails additional costs, such as registration, underwriting, underpricing, and annual disclosure costs. Pagano et al. (1998) identified adverse selection, administrative expenses and fees, and loss of confidentiality as the costs of going public.

3 Moreover, Brau and Fawcett (2006) examined motivations for conducting IPOs using an original questionnaire survey in the United States. Bodnaruk et al. (2008) examined shareholders' diversification and the decision to go public using data on IPOs in Sweden.
} 
although their effects diminish over time. To the best of our knowledge, few studies have examined the impact of initial conditions on the likelihood of an IPO. By focusing on start-up firms, we provide more conclusive evidence on the determinants of IPOs, in addition to new insights into the role of initial financial conditions in the IPO process. Such research enables us to elucidate the IPO decision in the growth process, which may also mitigate the problems associated with survivor bias and causality.

Meanwhile, IPOs become less attractive for start-up firms with growth potential. The number of IPOs in the United States-especially small-firm IPOs-decreased after 2000. While excessive regulatory costs, triggered by the Sarbanes-Oxley Act of 2002, may cause the low IPO volume, Gao et al. (2013) emphasized that small firms sell themselves out in a trade sale rather than to go public and remain independent, as these firms realize economies of scale and rapid product expansion through merger and acquisition (M\&A). Traditionally, M\&A (or trade sale) is considered an alternative to an IPO, and both IPO and M\&A are considered strategic sellouts (trade sales) of early-stage shareholders, including venture capitalists in the literature (e.g., Brau et al. 2003; Giot and Schwienbacher 2007; Poulsen and Stegemoller 2008). The benefits and costs of growing as an independent firm, compared to those of trade sales, are an important determinant of the decision to go public (Bayar and Chemmanur 2011; Signori and Vismara 2018). Thus, IPOs may become less attractive for some start-up firms with growth potential, despite the importance of equity financing for these firms.

\subsection{IPOs in junior stock markets}

Since the mid and late 1990s, some countries, such as Canada, European countries, and Japan, have introduced new stock markets (junior stock markets) following the National Association of Securities Dealers Automated Quotation (NASDAQ) in the United States, to provide equity financing for young firms with growth potential. To allow small and high-tech firms to go public without the burden of excessive regulations, stock exchanges have launched secondary and unregulated markets in Europe (Vismara et al. 2012). For instance, Alternative Investment Market (AIM) (United Kingdom; UK), Neuer Markt (Germany), Nouveau Marché (France), and Nuovo Mercato (Italy) have been launched since the mid and late 1990s. As the listing requirements in established stock exchanges are more stringent for young and small firms, these stock markets are designed to meet the needs of the firms (Ritter et al. 2013).

Junior stock markets were expected to provide equity financing opportunities for young IPO firms that achieve rapid growth, which would play a vital role in the revitalization and development of industries. Because of less stringent listing requirements, IPOs in these markets have accounted for a large portion of IPOs during the period 1995-2009 in the four largest European economies: France, Germany, Italy, and the UK (Vismara et al. 2012). However, despite the expectation of an increase in the number of IPOs, the number of IPOs decreased in and after 2008 in European countries (Vismara et al. 2012; Ritter et al. 2013; Akyol et al. 2014). This is due to 
the sluggish IPO markets affected by economic conditions. More importantly, firms' propensity to go public may be changed. Gao et al. (2013) suggested that small firms lose benefits from going public and conversely seek strategic sellouts through the M\&A alternative to IPOs using data on IPOs in the United States. Small firms may not rely exclusively on organic growth to expand.

It is of interest to highlight IPOs after the reform of stock exchanges in the mid and late 1990s, which would further advance the study of the promotion of young and innovative firms. Indeed, several studies have examined IPO and post-IPO performance, including the impact of regulations (listing requirements) of stock exchanges (e.g., Gerakos et al. 2013; Akyol et al. 2014). It is found that tightening regulations improve IPO survival, while easing of regulations tends to harm it (Cattaneo et al. 2015). However, although much attention has been paid to the IPOs of young and innovative firms, there is little evidence on how these firms secure equity financing through the creation of junior stock markets. How young and innovative firms conduct IPOs in the growth process remain an open question. Moreover, although an IPO seems to be less important as a strategic sellout in some countries, such as the United States, young and innovative firms may still seek external financing through an IPO in other countries. It is noteworthy to examine the IPOs of young and innovative firms in countries where IPOs are common as a strategic sellout.

\subsection{IPOs in Japan}

There have been fewer listings in Japan than in other countries, such as the United States. One reason for this is that listing requirements for young firms were much more strictly enforced in Japan (Matsuda et al. 1994).

Similar to the reform of stock exchanges in European countries, a trend toward the creation of new stock markets for innovative firms has been observed in Japan since the mid and late 1990s. In Japan, a special-rule issues market of the over-thecounter (OTC) market was opened in July 1995 to enable young and small firms investing heavily in R\&D to list their stocks, even though they ran deficits. ${ }^{4}$ Then, the Market of High-Growth and Emerging Stocks (MOTHERS) was opened on the Tokyo Stock Exchange (TSE) in November 1999 to target young and small firms with growth potential at an early stage of their development. Until the early 2000s, the stock markets of Ambitious, Centrex, Hercules, and Q-board were founded on established stock exchanges in Sapporo, Nagoya, Osaka, and Fukuoka, respectively. In addition, the OTC market in Japan was renamed "JASDAQ" after NASDAQ, and it was reorganized as a general stock exchange. In reality, JASDAQ and MOTHERS are major junior stock markets in Japan. While some European stock markets, such as Neuer Market (Germany) and Nouveau Marché (France), disappeared or merged in the 2000s, the Japanese stock markets, such as JASDAQ and MOTHERS, still exist (until 2019). Since a certain portion of firms listed on JASDAQ and

\footnotetext{
${ }^{4}$ However, only three firms were listed in this market, which was closed and absorbed into the original OTC market in December 1998.
} 
MOTHERS have been transferred to the main markets, such as the TSE, junior stock markets in Japan play a role of "feeder" (Granier et al. 2019).

Less stringent listing requirements in stock markets enable young and small firms to go public (Takahashi and Yamada 2015). The number of IPOs in junior stock markets is higher than in established stock exchanges in Japan: for example, 155 IPOs in junior stock markets and 33 IPOs in established stock exchanges in 2006, according to Kabusihi Kokai Hakusho (White Paper on Initial Public Offerings). However, the number of IPOs in junior stock markets decreased from 89 in 2007 to 42 in 2008, and it was the lowest with 13 in 2009. ${ }^{5}$ This trend in the Japanese stock markets is similar to that in the European stock markets discussed in Sect. 2.3.

Although junior stock markets for young and small firms have been introduced, Japan, as well as Germany, is traditionally considered as having a bank-centered capital market, in contrast to the United States, from a conventional perspective (Black and Gilson 1998). In Japan, the debt financing system, including bank loans, is well established and plays a critical role in providing funds to small businesses. Meanwhile, venture capital (VC) and business angel financing are advocated as important sources of financing for young and innovative firms (Block et al. 2018). However, Japan has the lowest level of investment by individuals in new businesses, and private equity financing from individual investors is limited (Honjo 2015). In addition, VC firms in Japan tend to invest in the early stages, and bridge financing is not easily available (Honjo and Nagaoka 2018). These notions suggest that Japan's private equity financial system is underdeveloped. In such countries, young and innovative firms may seek to acquire equity financing by accessing public equity markets, instead of private equity capital.

More importantly, in Japan, an IPO appears to be virtually established as the most successful sellout (exit) strategy for early-stage shareholders, including venture capitalists. One reason is that M\&A (trade sale) is less common as a strategic sellout in Japan than in other countries, such as the United States and European countries. ${ }^{6}$ Because of the less common M\&A and poor private equity financing system, some start-up firms seek IPOs to secure equity financing. In particular, start-up firms that require the external financing of innovative and uncertain businesses may seek access to public equity markets because of underdeveloped private equity capital in bank-centered financial systems, such as Japan. This also indicates that start-up firms that require equity financing must rely on public equity markets to secure

\footnotetext{
5 These numbers are counted, based on IPOs irrespective of firm age; therefore, they are much higher than IPOs in our sample.

6 According to Venture Enterprise Center (2015), the number of IPOs (116) among VC exits in Japan is higher than that of M\&A (36) in the 2014 fiscal year. In contrast, the number of IPOs in European countries and the United States is much lower than that of M\&A in 2014. Meanwhile, according to the Small and Medium Enterprise Agency (2009: p. 147), a large percentage of VC firms recovered investments through IPOs and selling back stock to company managers, but only $3.4 \%$ said that they had recovered investments through "selling to a third party." According to the Venture Capital Firms Supply Conditions Survey carried out by Tokyo Shoko Research, Ltd., the reasons why investment recovery is biased toward IPOs are that VC firms said that they "cannot make an adequate profit from any investment recovery methods other than IPOs," "M\&A markets are not well enough established," and they have "a lack of experience in recovering venture capital."
} 
external financing, while those without innovative and uncertain businesses can rely on bank loans. For start-up firms with innovative and uncertain businesses, including their early-stage shareholders, junior stock markets are imperative to secure external financing, especially for R\&D investment. Research on the determinants of an IPO in Japan will provide valuable insights into whether junior stock markets play a role in providing funds to young and innovative firms in countries depending heavily on bank financing. ${ }^{7}$

\section{Hypotheses development}

\subsection{Innovative and uncertain businesses}

As equity financing is not equivalent to debt financing, the likelihood of an IPO depends more on the demand for equity financing. The difference between debt and equity financing influences the decision to go public. We consider that the benefits and costs of going public are heterogeneous across firms and depend on firm-specific characteristics.

According to arguments in the literature, information asymmetries between startup firms and external suppliers of capital-specifically, high-tech start-ups and banks - in addition to the existence of uncertainties, prevent start-up firms from raising debt financing (e.g., Czarnitzki and Hottenrott 2011). While high-tech startups often require massive $R \& D$ investment, banks are reluctant to lend them money, primarily because it is difficult to evaluate their businesses and technologies. As discussed, equity financing has advantages over debt financing for high-tech investment (Carpenter and Petersen 2002a; Hall 2002; Colombo and Grilli 2007). It is conceivable that start-up firms that engage in innovative and uncertain businesses have an incentive to go public early to secure equity financing for a large amount of investment, including R\&D. These firms require early access to public equity markets to continue their projects, partly because bridge financing is underdeveloped in Japan (Honjo and Nagaoka 2018). Moreover, early-stage shareholders may pursue IPOs to sell their highly risky shares. Thus, we consider the following hypothesis:

H1 Start-up firms that engage in innovative and uncertain businesses are more likely to go public earlier than others

However, going public has the disadvantage of releasing confidential information to competitors that can then compete more effectively with the firms going public (Chemmanur et al. 2010). In particular, firms in high-tech sectors may have less incentive to go public due to the loss of confidentiality (Pagano et al. 1998). These firms are reluctant to reveal detailed information about projects, as required by outside lenders, fearing disclosure to potential rivals (Campbell 1979; Yosha 1995).

\footnotetext{
7 For more studies on IPOs in Japan, see, for example, Honjo (2001), Honjo and Kutsuna (2010), Yamada (2013), Takahashi and Yamada (2015), and Takahashi (2018).
} 
This study examines whether start-up firms that engage in innovative businesses have more incentive to go public, which would provide evidence on the validity of the loss of confidentiality.

\subsection{Initial capital structure}

Previous studies have argued the importance of an IPO alternative to financing. Access to new finance is one of the most important reasons for going public (Röell 1996). Firms can mitigate the debt overhang and other agency problems in future by reducing debt financing and strengthening equity financing. Gaining access to an alternative source of finance to banks provides benefits to firms, enabling the firms to rebalance their accounts (Pagano et al. 1998). Entrepreneurs expect to reduce borrowing costs by creating new access to finance, which will lead to higher valuation of firms by gaining more profits. A firm's portfolio choice of borrowing sources circumscribes the power of banks (Rajan 1992). By gaining access to public equity markets and disseminating information to general investors, firms elicit outside competition to their lenders and ensure a lower cost of credit (Rajan 1992; Pagano et al. 1998). Therefore, start-up firms that rely heavily on debt financing have a greater incentive to rebalance their capital structures by going public. Highly leveraged firms seek to go public to reduce financing costs. These firms may mitigate borrowing constraints through IPOs to obtain a stronger bargaining position against banks owing to the availability of an alternative source of funds. In practice, some empirical studies found that leverage is positively associated with the decision to go public (Aslan and Kumar 2011; De Jong et al. 2012). Thus, we consider the following hypothesis, namely, "rebalance hypothesis."

H2a Start-up firms that rely heavily on debt financing are more likely to go public earlier than others

However, although Pagano et al. (1998) argued that firms need to obtain a stronger bargaining position against banks, they found no significant effects of leverage, bank rate, and concentration borrowing on the likelihood of an IPO. In fact, few studies attempt to explain why firms that can rely on debt financing require access to public equity markets. If firms maintain debt financing through good relationships with banks, they have less incentive to rebalance their capital structures by accessing public equity markets. Firms that rely heavily on bank loans as initial funding may expect benefits from debt financing. Such firms hope to maintain good relationship with banks because relationship lending helps attenuate the asymmetric information problems (Petersen and Rajan 1994; Berger and Udell 1995). Conversely, banks are reluctant to lend money to firms that they do not have strong relationships with. Rather, firms that cannot rely on bank loans as initial funding may prefer equity financing to debt financing.

According to the resource-based view, the entrepreneurial process depends on the sources the entrepreneurs acquire and develop, and new business outcome is to a large extent determined by the nature of the sources the entrepreneurs can acquire 
(Aspelunda et al. 2005). In this context, initial financial conditions represent entrepreneurs' capacity about how entrepreneurs can raise funds at founding. Some studies have emphasized the importance of initial conditions in the literature on entrepreneurship and small business (e.g., Cooper et al. 1994). It is plausible that initial financial conditions play a key role in the IPO decision. A firm's access to funding sources prior to an IPO influences the decision to go public. Rather, initial financial conditions may determine the future sources of financing - the path of the firm's growth process.

Bhamra et al. (2010) emphasized the path dependence of capital structure. Given the existence of path dependence in the firm's financing, it is conceivable that initial funding - specifically, debt or equity financing-predicts financing strategies, including IPOs. According to the path dependence of capital structure, start-up firms that rely on equity financing at founding have more incentives to access public equity markets in their growth process. It is plausible that these firms expect the benefits of going public. The shareholders of these firms may have stronger control rights than creditors (banks) and an incentive to go public due to benefits from the liquidity of shares, such as high capital gains, in addition to better reputation through an IPO by disseminating information to general investors. Eventually, such firms seek IPOs; thus, we consider the opposite hypothesis to H2a, namely "path dependence hypothesis," as follows:

H2b Start-up firms that rely heavily on equity financing are more likely to go public earlier than others

Little is known about the impact of initial financial conditions on the IPO decision in the growth process of firms. We examine the effect of initial capital structure on the likelihood of an IPO to test if the financing of start-up firms follows the rebalance hypothesis or the path dependence hypothesis.

Additionally, Holmström and Tirole (1993) focused on short- and long-term incentives and showed that the fraction of firms going public increases with the amount of long-term capital. Following their model, long-term financing, rather than debt financing, may have a stronger impact on the likelihood of an IPO. This study also examines whether start-up firms that rely heavily on long-term capital are more likely to go public earlier than others, using more detailed account items about equity capital as covariates.

\subsection{Growth opportunities and market timing}

Essentially, the IPO decision depends on the benefit of going public, which may be significantly associated with future growth opportunities. Start-up firms with growth opportunities presumably demand funds for investment, although they may encounter financial constraints due to a large amount of investment. Therefore, start-up firms with growth opportunities are more likely to go public earlier than others, in order to secure alternative sources of finance. Meanwhile, some scholars posit that managers strategically determine IPOs to take advantage of 
"window of opportunity" in stock markets that allow higher offer price (e.g., Pagano et al. 1998; Aslan and Kumar 2011). The window of opportunity is particularly appealing for shareholders, including entrepreneurs, who seek large capital gains through an IPO. For these reasons, it is conceivable that growth opportunities have a significant impact on the likelihood of an IPO; thus, we test the following hypothesis:

H3 Start-up firms with growth opportunities are more likely to go public earlier than others

Furthermore, the likelihood of an IPO also depends on stock market conditions. The literature on corporate finance has argued that the IPO market exhibits dramatic swings in issuance, which are often referred to as hot and cold markets (e.g., Ibbotson and Jaffe 1975; Ritter 1984; Helwege and Liang 2004). It is also found that the likelihood of an IPO is positively affected by the stock market valuation of firms (e.g., Pagano et al. 1998; Signori and Vismara 2018). Firm are more likely to go public when equity valuations are high, and they may employ private financing when values are lower (Lerner 1994). Based on these arguments, we test the following hypothesis:

H4 Start-up firms are more likely to go public when market conditions are more favorable

IPOs should be compared with their counterparts by controlling for firm heterogeneity and different conditions. As described in the following section, when testing the above hypotheses, we control for some factors, such as capital expenditures and initial firm size.

\section{Methods}

\subsection{Survival analysis}

A firm having experienced an IPO once does not need to conduct an IPO. In addition, the time to an event-IPO in this study-is not always observed for all firms in the observation window. Therefore, the time to IPO can be regarded as duration data, and right censoring is the most common in the analysis. In this case, a survival analysis framework is better for estimating the determinants of the time to IPO. Using this framework, we investigate the IPO process while tracing the history of firms from founding. It is important to note that the literature on the postentry performance of firms measures time by firm age (e.g., Mata and Portugal 1994; Audretsch and Mahmood 1995; Mata et al. 1995). We employ two methods: the cumulative hazard function (non-parametric approach) and the proportional hazards and competing-risks regressions (semi-parametric approach). We describe the 
cumulative hazard function using the method proposed by Nelson (1972) and Aalen (1978). ${ }^{8}$

Let $T_{i}$ denote the time from founding to IPO for firm $i$; that is, $T_{i}$ indicates how long it takes for firm $i$ to conduct an IPO after founding. Let $C_{i}$ denote the censoring time, which is the duration of the observation window for firm $i$, and the time to IPO, $T_{i}$, is observed if $T_{i} \leq C_{i}$. Suppose that the time to IPO is observed for $n$ firms in the sample and $T_{1} \leq T_{2} \leq \cdots \leq T_{n}$. In this case, the cumulative hazard function proposed by Nelson (1972) and Aalen (1978) is given by

$$
\hat{H}(t)=\sum_{j \mid T_{j}<t}^{n} \frac{d_{j}}{n_{j}} .
$$

where $d_{j}$ is the number of firms that experience the event at time $T_{j}$, and $n_{j}$ is the number of firms that have not yet conducted an IPO at that time. Following Eq. (1), we obtain the cumulative hazard estimates of IPOs.

\subsection{Proportional hazards and competing risks regressions}

To show the factors affecting the time to IPO, we employ a proportional hazards regression proposed by Cox (1972). In general, the hazard (function), $h_{i}(t)$, is defined as follows:

$$
h_{i}(t)=\lim _{\Delta t \rightarrow 0} \frac{\operatorname{Pr}\left(t<T_{i} \leq t+\Delta t \mid T_{i}>t\right)}{\Delta t} .
$$

In the proportional hazards regression, the hazard is assumed to be written by

$$
h_{i}(t ; x)=h_{0}(t) \exp \left(x_{i}^{\prime} \beta\right),
$$

where $x_{i}$ is the vector of the covariates affecting the IPO; $\beta$ is the vector of estimated parameters (coefficients); and $h_{0}(t)$ is the baseline hazard. To estimate $\beta$ and the hazard ratio, we specify the following likelihood function, $L$ :

$$
L=\prod_{j=1}^{n} \frac{h_{0}(t) \exp \left(x_{j}^{\prime} \beta\right)}{\sum_{k \in R_{j}} h_{0}(t) \exp \left(x_{k}^{\prime} \beta\right)}=\prod_{j=1}^{n} \frac{\exp \left(x_{j}^{\prime} \beta\right)}{\sum_{k \in R_{j}} \exp \left(x_{k}^{\prime} \beta\right)},
$$

where $R_{j}$ is a risk set at $T_{j}$ and firm $k$ satisfies the condition that $T_{j}<T_{k}$.

However, the estimation has an issue. Some IPOs cannot be observed when firms are forced out of business before going public. The presence of a competing event may impede the event of interest, which is an IPO in this analysis. To take into

\footnotetext{
${ }^{8}$ In this study, we capture the time from founding to IPO, which is similar to the method used in Honjo and Nagaoka (2018). We also employ the cumulative hazard function and the competing risks regression, following previous studies (e.g., Honjo and Kato 2019). Giot and Schwienbacher (2007) examined the time to IPO, trade sale, and liquidation from the viewpoint of venture capitalists, using the competing risks regression.
} 
account the different types of events other than an IPO, we employ a competing risks regression. Specifically, the competing events prior to the IPO, such as firm exits due to business failure, tend to occur during the start-up period. Considering the competing events prior to the IPO will significantly improve the estimation method for the decision to go public.

More precisely, $T_{i}$ is observable if a firm goes public up to the censoring time, $C_{i}$, and the firm is not forced out of business; otherwise, $T_{i}$ is unobservable. There are two events in the analysis: an IPO and an exit, which is a competing event alternative to an IPO. Let $\tilde{T}_{i}$ denote the time from founding to the competing event for firm $i$. We observe either an IPO or the competing event when $\min \left\{T_{i}, \tilde{T}_{i}\right\} \leq C_{i}$. Gray (1988) and Fine and Gray (1999) proposed the hazard of the sub-distribution for the competing event. Following the specification, we formalize the hazard for an IPO, $\bar{h}_{i}(t)$, as follows:

$$
\bar{h}_{i}(t)=\lim _{\Delta t \rightarrow 0} \frac{\operatorname{Pr}\left(t<T_{i} \leq t+\Delta t \mid C_{i} \wedge T_{i}>t \cup \tilde{T}_{i} \leq t\right)}{\Delta t},
$$

where $a \wedge b$ denotes $\min \{a, b\}$. To estimate the determinants of an IPO, we assume that its subdistribution hazard is written as follows:

$$
\bar{h}_{i}(t ; x)=\bar{h}_{0}(t) \exp \left(x_{i}^{\prime} \gamma\right),
$$

where $\gamma$ is the vector of estimated parameters (coefficients) and $\bar{h}_{0}(t)$ is the baseline sub-hazard. Using the similar likelihood function shown in Eq. (3), we obtain $\gamma$ and the hazard ratio.

\section{Data}

\subsection{Data sources}

The data set used in the analysis is extracted from a database compiled by Teikoku Databank, Ltd. (TDB), which is one of the major credit investigation companies in Japan (comparable to Dun \& Bradstreet in the United States). The TDB database comprises unconsolidated financial statements prepared using the Japanese Generally Accepted Accounting Principles. We obtained data on financial statements in the first (initial) accounting year after founding (incorporating). ${ }^{9}$ Using the TDB database, we identified the IPOs of start-up firms, including stock markets. We also obtained data on market indices from the Nikkei Needs Financial Quest.

In Japan, there are several legal forms of firms, including sole proprietorship and partnership. While sole proprietorship and partnership are introduced as forms of private holding, a joint-stock company is the most typical form of a limited liability company. In this study, we target joint-stock companies, mainly because the TDB

\footnotetext{
9 We do not have data on all firms' financial statements for the second and any later accounting years and information about entrepreneurs' personal attributes and ownership structure.
} 
database does not sufficiently cover the financial statements of sole proprietorships and partnerships. In addition, there is very little possibility of sole proprietorships and partnerships going public within a short period of time. In this study, we could ensure a certain number of IPOs by focusing on join-stock companies.

Using the TDB database, we constructed the sample of start-up firms founded from the mid-1990s when the junior stock markets were introduced in Japan, in order to identify the factors affecting the time to IPO. For our sample, we selected firms incorporated from January 1995 to December 2010. To observe the IPO event, we set up an observation window from January 1995 to January 2011. This observation window was set before the Great East Japan Earthquake in March 2011. While the day, month, and year are specified for the firm's IPO event, only month and year are specified for a part of the firm's founding and other event dates in the data source. In this study, we measure the time to IPO by month, although the time to IPO for most firms is censored. We observe the time to IPO in the range of 1 month (for firms founded in December 2010) to 192 months (for firms founded in January 1995) in the sample. Generally, several IPOs were made from the early2000s, mainly because junior stock markets were introduced from the mid-1990s to the early 2000s, and the so-called "Internet bubble" occurred around 2000 in Japan. However, the number of IPOs decreased drastically in 2008 because of the recession along with the collapse of Lehman Brothers. Therefore, it is predicted that the likelihood of an IPO depends heavily on market conditions in Japan.

The sample covers firms in the manufacturing, information and communications technology (ICT), wholesale and retail trade, and service sectors. ${ }^{10}$ This contrasts with some earlier studies that focused only on start-up firms in the manufacturing sector (e.g., Huyghebaert et al. 2007). Although high-tech start-ups, which require massive $\mathrm{R} \& \mathrm{D}$ expenditures, tend to be included in the manufacturing sector, this sector is progressively contracting in most developed countries, including Japan. In practice, the ICT and service sectors, rather than the manufacturing sector, have attracted many new entrants in recent years, and these industries seem to contribute the most to future economic growth.

The sample included a few large firms. Although these firms might possibly be de-novo entrants, those with 500 employees and more in the first accounting year were considered as outliers, and we excluded these from the sample. In addition, a few firms went public within 1 month after founding because of the reorganization of group firms. We excluded these firms from the sample. Moreover, we excluded some firms regarded as outliers from the sample. Consequently, the sample comprises 10,397 joint-stock companies founded in Japan from 1995 to $2010 .^{11}$

\footnotetext{
10 From the sample, we exclude firms in relatively unimportant sectors or those in highly regulated industries, such as agriculture, forestry, fisheries, mining, finance, insurance, and public services. We also exclude firms in the construction sector because the TDB database tends to extremely cover firms in this sector but most firms do not go public.

11 In Japan, regulations related to minimum paid-in capital requirements-more precisely, capital stock of no less than 10 million yen for a joint-stock company-were in place in and after April 1990, as a means of increasing initial equity financing, even for small firms. The regulations mandated entrepreneurs to obtain 10 million yen in capital to found joint-stock companies. However, the requirements were
} 
Table 1 describes the distribution of IPOs in the sample. The interest event targets IPOs not only in established stock exchanges, such as TSE, but also in junior stock markets, such as JASDAQ and MOTHERS. Among the start-up firms, 109 had experience in IPO by January 2011. In practice, all 109 firms went public in junior stock markets. In this respect, junior stock markets play a critical role in providing equity capital to start-up firms in Japan. Table 1 also presents the distribution of firm exits, except for IPOs, which is regarded as a competing event for an IPO in this study. In the sample, 1092 firms exited due to merger, business failure (bankruptcy) or others in the observation window. The proportion of firm exits is more than 10\% in the sample. Among the 1092 firms, 489 firms merged, 537 firms failed, and 66 firms exited due to other reasons. While 1085 firms that had experience in the competing event (firm exit) prior to an IPO did not conduct IPOs, seven IPO firms exited in the observation window. In Table 1, we also find that the proportion of firm exits for non-IPOs $(10.6 \%)$ is higher than that for IPOs $(6.4 \%)$. This suggests that non-IPO firms (privately held firms) are more likely to disappear than IPO firms (publicly listed firms), indicating that "public or perish."

Moreover, Table 2 describes the descriptive statistics of the time from founding to IPO. On average, the time to IPO is approximately 57 months for the 109 IPO firms. In the sample, the earliest IPO is November 1997, and the minimum time to IPO is 10 months (297 days) for an ICT start-up. Table 2 also presents the time to merger and to failure, in addition to the time to firm exit. On average, the time to merger and failure are both longer than the time to IPO. ${ }^{12}$

\subsection{Covariates}

Following the hypotheses discussed in Sect. 3, we define the covariates affecting the time to IPO. Although it is difficult to identify innovative and uncertain businesses, we propose two proxies that are obtainable from financial statements. First, $R \& D$ activities are used to capture innovative businesses. We measure R\&D activities (RD) using the dummy for R\&D expenditures in the first accounting year. R\&D activities include not only $R \& D$ expenditures but also patent royalty payments, which are reported in income statements. ${ }^{13}$ Moreover, several start-up firms,

\footnotetext{
Footnote 11 (continued)

removed when the new Companies Act was introduced in May 2006. Therefore, from the sample, we excluded firms with less than 10 million yen for firms founded before May 2006. Moreover, we excluded the following firms as outliers; specifically (i) equity financing was zero, negative or unavailable, (ii) capital surplus was negative, (iii) paid-in capital (capital stock plus capital surplus) plus treasury shares was zero, (iv) fixed tangible assets were unavailable, (v) tangible assets were negative, or (vi) total assets were zero.

12 As Tables 1 and 2 show, only a few firms exit after going public. Recent studies examined post-IPO mergers and merger synergies (e.g., Bade 2018; Signori and Vismara 2018), and it may be interesting to examine the likelihood of a merger among IPO firms. This will probably remain as a future subject.

13 Instead of the dummies, the covariates for innovative and uncertain businesses can be defined as the ratio measures, such as the ratio of $R \& D$ expenditures to sales. However, such ratios differ considerably between start-up firms, partly because a few firms have massive R\&D expenditures, and some firms spend a small amount, probably due to financial constraints. Therefore, we simply identify innovative and uncertain businesses using the dummies.
} 
Table 1 Distribution of IPOs and firm exits

\begin{tabular}{lllllll}
\hline \multirow{2}{*}{ Survival } & Firm exit & & \multicolumn{2}{c}{ Total } \\
\cline { 3 - 5 } & & & Merger & Failure & Others & \\
\hline Non-IPO & $9203(89.5 \%)$ & $1085(10.6 \%)$ & $486(4.7 \%)$ & $533(5.2 \%)$ & $66(0.6 \%)$ & $10,288(100.0 \%)$ \\
IPO & $102(93.6 \%)$ & $7(6.4 \%)$ & $3(2.8 \%)$ & $4(3.7 \%)$ & $0(0.0 \%)$ & $109(100.0 \%)$ \\
Total & $9305(89.5 \%)$ & $1092(10.5 \%)$ & $489(4.7 \%)$ & $537(5.2 \%)$ & $66(0.6 \%)$ & $10,397(100.0 \%)$ \\
\hline
\end{tabular}

Figures in parentheses are the percentages of frequencies in the column by row. "Non-IPO" and "IPO" indicate whether the firm remains private or goes public during the observation window (from the firm's founding date to January 2011). While "survival" indicates that the firm survives during the observation window, "firm exit" indicates that the firm does not survive. "Firm exit" is classified into the following three types: "merger," "failure," and "others"

including university spin-offs, may seek to commercialize technologies developed before founding. Therefore, the dummy for R\&D activities includes the allocation of intellectual assets, such as patent, utility model, trademark, and design rights, which are reported in balance sheet statements.

Then, we identify uncertain businesses using capital flexibility (FLEX) measured by capital surplus. Generally, initial equity capital consists of paid-in capital that can be divided into two parts: capital stock (stated capital) and capital surplus (legal capital reserves). According to the Company Law (Act 445 (2)) in Japan, the amount not exceeding a half of the amount of paid-in capital may not be recorded as capital stock (stated capital). Meanwhile, alternation in capital stock is stricter than in capital surplus because altering capital stock requires decision in shareholder meetings. When firms with cumulative deficits reduce equity capital, they can offset their cumulative deficits using capital surplus without alternation in capital stock. In other words, capital surplus represents flexible equity capital, while capital stock represents stable equity capital in paid-in capital. Therefore, it is considered that start-up firms with uncertain businesses prefer capital surplus to capital stock, in order to maintain the flexibility of equity capital. ${ }^{14}$ It is also likely that entrepreneurs recognize their projects as high risk when they use capital surplus at founding; that is, the initial use of capital surplus may represent entrepreneurs' perception of business uncertainty. Using these two proxies, we examine whether H1 is supported, and disentangle the effects of innovative and uncertain businesses on the time to IPO. ${ }^{15}$

We define initial capital structure $(\mathrm{E} / \mathrm{TF})$, measured by the ratio of equity financing to debt and equity financing in the first accounting year, to identify which hypothesis is supported: the rebalance hypothesis $(\mathrm{H} 2 \mathrm{a})$ or the path dependence hypothesis (H2b). In this study, equity financing is the sum of capital stock, deposits

\footnotetext{
14 Firms may use capital surplus for tax reduction because small firms whose capital stock is no more than 100 million yen often have advantages of tax payment in Japan.

15 Share warrants, including convertible and warrant bonds, are associated with stock options, and this equity financing may also be regarded as uncertain business. However, the proportion of start-up firms using share warrants in the first-accounting year is considerably small (only 51 firms). Thus, we do not capture uncertain business using share warrants.
} 
Table 2 Descriptive statistics of the time to IPO and firm exit

\begin{tabular}{lcccccrrr}
\hline & Mean & SD & Min. & $25 \%$ & Median & $75 \%$ & Max. & N \\
\hline Time to IPO & 56.6 & 28.0 & 10 & 34 & 55 & 71 & 152 & 109 \\
Time to firm exit & 75.0 & 37.5 & 9 & 44 & 70 & 102 & 185 & 1092 \\
Time to merger & 68.6 & 36.2 & 9 & 41 & 61 & 92 & 185 & 489 \\
Time to failure & 76.9 & 36.8 & 14 & 46 & 72 & 103 & 179 & 537 \\
\hline
\end{tabular}

All figures are measured by the number of months

$\mathrm{SD}$ indicates standard deviation; $\mathrm{N}$ indicates the number of observations

for subscriptions to shares, capital surplus, share warrants, and convertible and warrant bonds, while debt financing is the sum of short- and long-term loans payable to inside and outside creditors, commercial paper, and corporate bonds. In addition, we use a covariate for the long-term capital ratio (LONG/TF) to examine whether, as Holmström and Tirole (1993) indicated, start-up firms that rely heavily on long-term capital are more likely to go public earlier than others. In this study, long-term capital is defined as the sum of equity financing and long-term debt financing.

In the literature, growth opportunities have often been measured by a market-tobook ratio (e.g., Pagano et al. 1998). Following these studies, we use a covariate for the industry's market-to-book ratio (MTB), which is measured using the median market-to-book ratio in the firm's same industry in its founding year. We clarify the differences in the growth opportunities of start-up firms between industries, using this covariate, and examine whether $\mathrm{H} 3$ is supported. Moreover, the likelihood of an IPO depends heavily on market conditions, including deregulations in stock markets. Therefore, we define market conditions (JINDEX) using the JASDAQ index, which is a market capitalization-weighted index provided by the TSE, to examine whether H4 is supported. The JASDAQ index was calculated at 100 on December 28, 1991. This index was 55.25 at the end of January 1995 and 52.30 at the end of December 2010. When we use the JASDAQ index in the analysis, the values are normalized to one at the end of January $1995 .{ }^{16}$ Using this covariate, we also control for different macroeconomic conditions between firms, as the sample consists of start-up firms founded from 1995 to 2010.

Some controls are included in the regressions. We capture capital expenditures (CAPEX) using the tangible fixed assets ratio, following previous studies (e.g., Pagano et al. 1998; Chemmanur et al. 2010; Aslan and Kumar 2011; De Jong et al. 2012; Cattaneo et al. 2015). While the demand for funds increases with capital expenditures, start-up firms with higher capital expenditures may be able to secure collateral for bank loans, resulting in start-up firms' relying on debt financing. In addition, previous studies have found that firm size has a positive impact on the likelihood of going public (e.g., Pagano et al. 1998; Chemmanur et al. 2010; Aslan and Kumar 2011; De Jong et al. 2012; Cattaneo et al. 2015). Indeed, large firms have

\footnotetext{
${ }^{16}$ Although the TSE provides other indices for junior stock markets, such as the J-stock index, only the JASDAQ index is obtainable for the period 1995-2010.
} 
advantages in obtaining the required numbers of shareholders and floating shares, which, generally, are composed of listing requirements in stock markets. Initial firm size may also indicate a level of commitment to business expansion. To control for firm size, we measure initial firm size (SIZE) using the number of employees in the first accounting year. In addition, to identify the differences between industries, we use industry dummies for manufacturing, ICT, and service sectors (I_MANU, I_ICT, and I_SERV). ${ }^{17}$ Moreover, some start-up firms may be created as spin-offs of parent firms, and R\&D-intensive spin-offs may differ from others (Helm and Mauroner 2007). We include the dummy for subsidiaries and affiliated firms (SUB) in the regression model. ${ }^{18}$ Furthermore, we include entry cohort dummies for 2 years (Y95_96, Y97_98, ...) in the regressions when not using JINDEX. ${ }^{19}$ The entry cohort dummies that represent the entry years of start-up firms, as well as MTB and JINDEX, may control for macroeconomic conditions due to differences in entry timing between start-up firms. Table 3 presents the definitions of these covariates.

Table 4 describes the descriptive statistics of covariates used in this study. The covariates RD, FLEX, E/TF, LONG/TF, CAPEX, and SIZE are constructed from financial statements in the first accounting year. Using these covariates, we capture initial financial conditions associated with the time to IPO. We also use the covariate JINDEX, which is time variant and varies by month, while the others are time invariant.

\section{Results}

\subsection{Cumulative hazard estimates}

Before estimating the determinants of IPOs in Eqs. (3) and (6), we show differences in the likelihood of an IPO, according to innovative and uncertain businesses. Using the dummies for R\&D activities (RD) and capital flexibility (FLEX), we classify start-up firms into two groups, innovative and risky start-ups $(=1)$ and others $(=0)$, respectively. Table 5 presents differences in IPOs between the two groups. We also provide log-rank test statistics to show the significant differences between them. Moreover, Fig. 1 depicts the cumulative hazard estimates of IPOs for the two groups, following Eq. (1). As Table 5 shows, the number of IPOs for innovative and

\footnotetext{
17 The reference category for the industry dummies is wholesale and retail trade.

18 It is plausible that the IPO decision for start-up firms depends on ownership structure and corporate policies. Many studies have highlighted the vital role of VC firms and the performance of VC-backed firms (e.g., Puri and Zarutskie 2012; Bertoni et al. 2015). Moreover, some scholars have focused on the structure and governance of IPO firms (e.g., Audretesch and Lehmann 2013). However, we cannot examine the effects of ownership structure and control on the likelihood of an IPO because it is difficult to obtain data on ownership structure and the timing of acquisitions (not mergers) from the TDB database. In this study, we simply identify whether the firm is a subsidiary or an affiliated firm in the database, regardless of the timing of the parent firm's ownership, to control for the existence of parent firms. Further investigation is warranted.

19 We define the covariates by 2 years because no IPO firms are available in a year when defining them by a single year.
} 


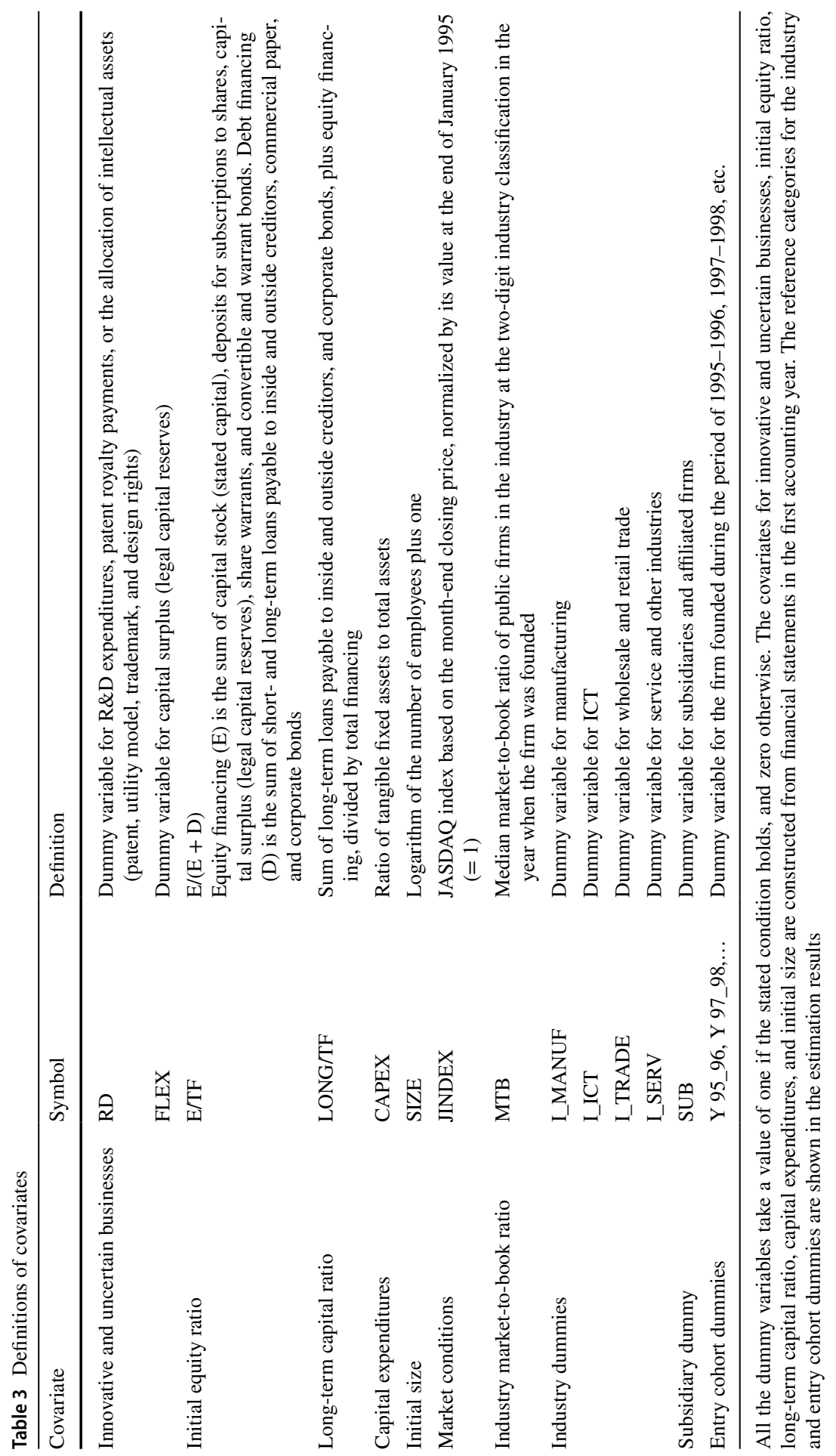


Table 4 Descriptive statistics of covariates

\begin{tabular}{lclllll}
\hline Covariate & Mean & SD & $25 \%$ & Median & $75 \%$ & N \\
\hline RD & 0.113 & - & - & - & - & 10397 \\
FLEX & 0.069 & - & - & - & - & 10397 \\
E/TF & 0.597 & 0.354 & 0.263 & 0.592 & 1.000 & 10397 \\
LONG/TF & 0.826 & 0.267 & 0.723 & 1.000 & 1.000 & 10397 \\
CAPEX & 0.105 & 0.173 & 0.000 & 0.027 & 0.123 & 10397 \\
SIZE & 1.871 & 1.240 & 1.099 & 1.792 & 2.565 & 10397 \\
JINDEX & 1.181 & 0.417 & 0.875 & 1.032 & 1.515 & 700469 \\
MTB & 1.404 & 1.396 & 0.790 & 1.025 & 1.576 & 10397 \\
I_MANUF & 0.107 & - & - & - & - & 10397 \\
I_ICT & 0.233 & - & - & - & - & 10397 \\
I_TRADE & 0.383 & - & - & - & - & 10,397 \\
I_SERV & 0.277 & - & - & - & - & 10,397 \\
SUB & 0.251 & - & - & - & - & 10,397 \\
Y95_96 & 0.068 & - & - & - & - & 10,397 \\
Y97_98 & 0.063 & - & - & - & - & 10,397 \\
Y99_00 & 0.096 & - & - & - & - & 10,397 \\
Y01_02 & 0.088 & - & - & - & - & 10,397 \\
Y03_04 & 0.101 & - & - & - & - & 10,397 \\
Y05_06 & 0.160 & - & - & - & - & 10,397 \\
Y07_08 & 0.226 & - & - & - & - & 10,397 \\
Y09_10 & 0.199 & - & - & - & - & 10,397 \\
Number of employees & 15.556 & 38.761 & 2.000 & 5.000 & 12.000 & 10,397 \\
\hline
\end{tabular}

The descriptive statistics of JINDEX is based on the estimation results for the time to IPO and IPO/ merger reported in column (v) of Tables 6 and 7

$\mathrm{SD}$ indicates standard deviation; $\mathrm{N}$ indicates the number of observations

Table 5 Log-rank tests: IPOs and firm exits of innovative/uncertain businesses and others among startup firms

\begin{tabular}{lcccccc}
\hline Covariate & IPO & Expected & Log rank & Firm exit & Expected & Log rank \\
\hline RD & & & & & & \\
0 & 77 & 95.7 & $29.9^{* * *}$ & 946 & 958.0 & 1.23 \\
1 & 32 & 13.3 & & 146 & 134.0 & \\
FLEX & & & & & & \\
0 & 68 & 102.5 & $197^{* * *}$ & 989 & 1031.8 & $32.6^{* * *}$ \\
1 & 41 & 6.5 & & 103 & 60.2 & \\
Total & 109 & 109.0 & & 1092 & 1092.0 & \\
\hline
\end{tabular}

"IPO" indicates the number of IPOs in the observation window (from the firm's founding date to January 2011). "Firm exit" indicates the number of firm exits in the observation window. "Firm exit" includes the following three types: "failure," "merger," and "others." "Expected" indicates the expected values. "Log rank" indicates the log-rank test statistics 
Panel (a): R\&D activities (RD)

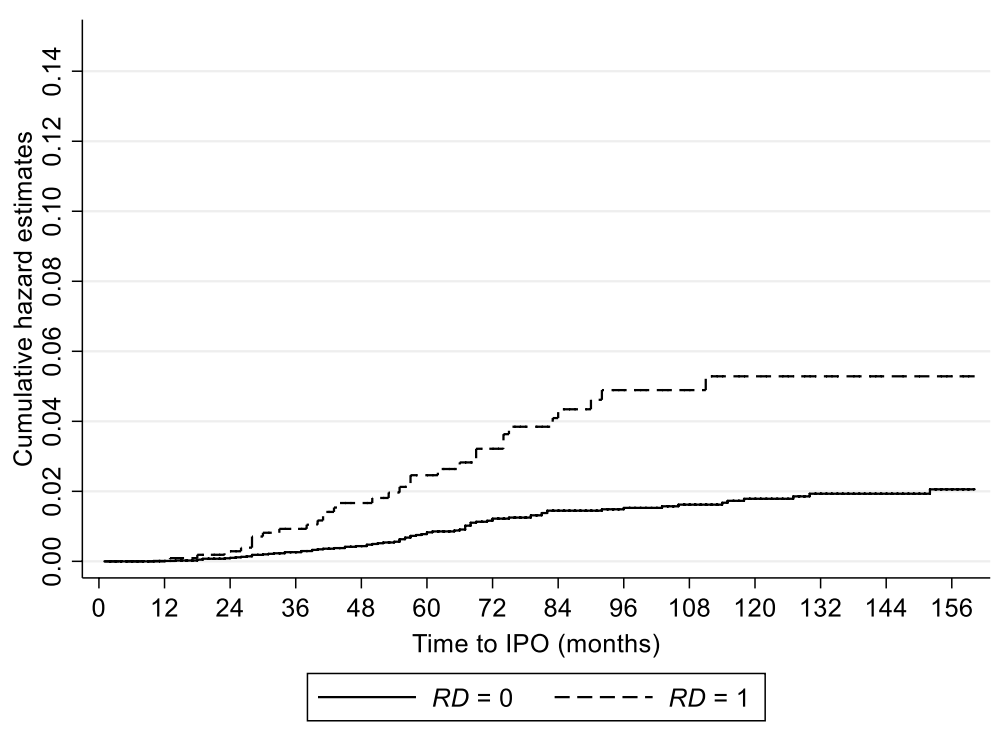

Panel (b): Capital flexibility (FLEX)

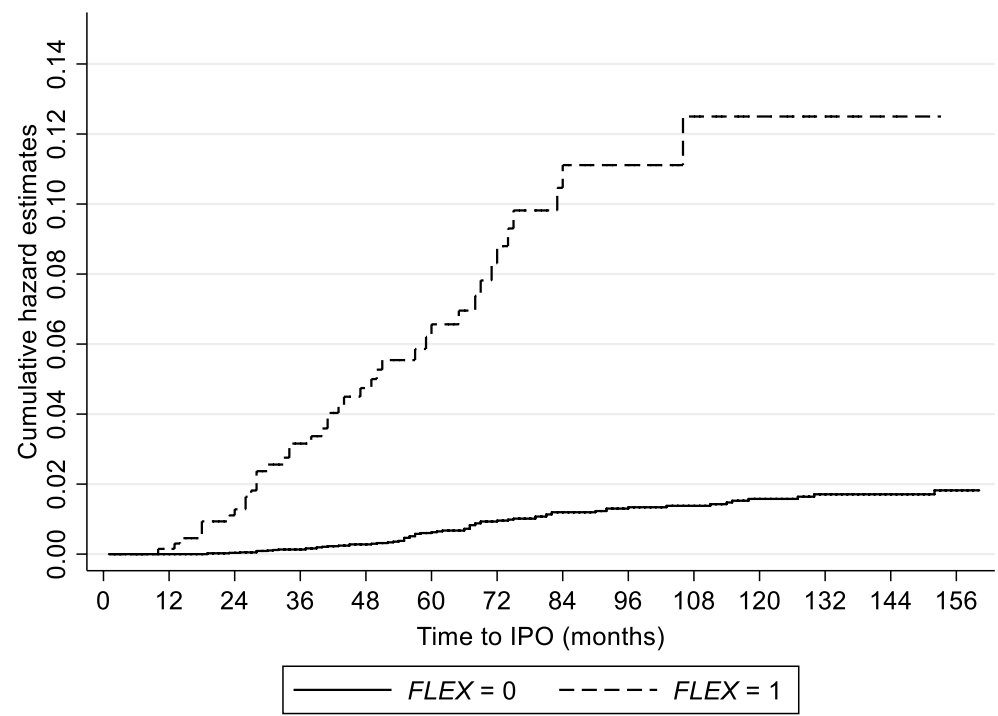

Fig. 1 Cumulative hazard estimates of IPOs. Source: Author's elaboration based on the TDB database

risky start-ups is higher than expected IPOs. As Fig. 1 shows, the cumulative hazard estimates of IPOs for innovative and risky start-ups tend to increase faster than for others. These results indicate that start-up firms that engage in innovative and uncertain businesses are more likely to go public earlier than others. 
Panel (a): R\&D activities (RD)

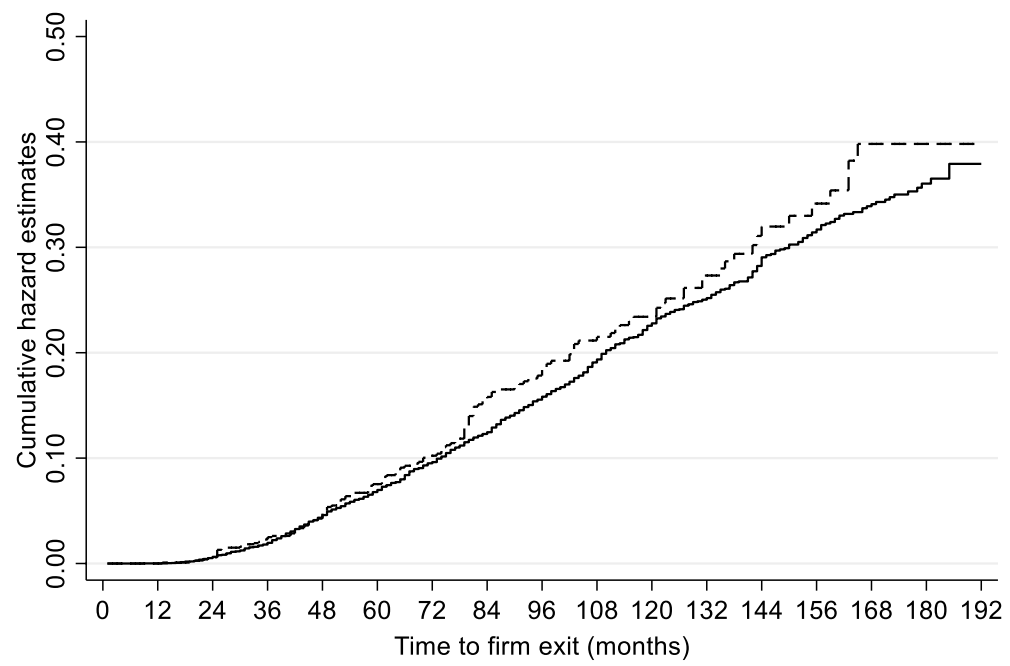

$R D=0 \quad-----R D=1$

Panel (b): Capital flexibility (FLEX)

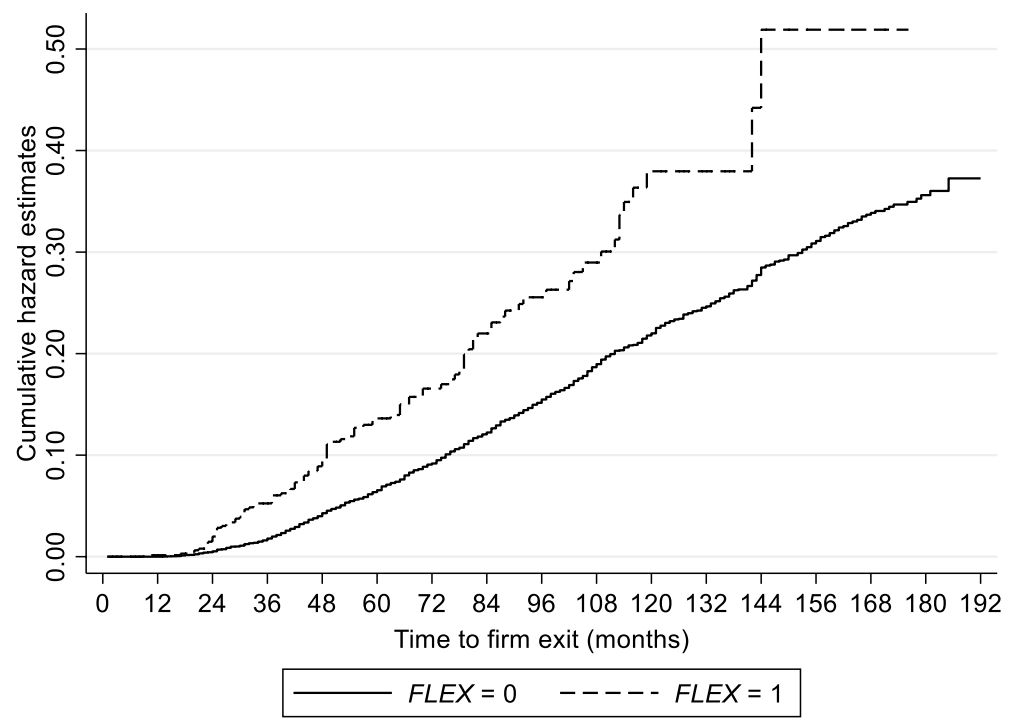

Fig. 2 Cumulative hazard estimates of firm exits. Source: Author's elaboration based on the TDB database

Table 5 also presents differences in firm exits between the two groups. Following Fig. 1, Fig. 2 depicts the cumulative hazard estimates of firm exits for the two groups. As shown in the table and figure, the cumulative hazard estimates of firm 
exits regarding R\&D activities (RD) do not differ between the two groups. Meanwhile, the cumulative hazard estimates of firm exits regarding capital flexibility (FLEX) differ between the two groups. These results indicate that start-up firms that engage in uncertain businesses measured by capital flexibility are more likely to disappear earlier than others, and the difference is backed up by the log-rank test.

\subsection{Determinants of the time to IPO}

Table 6 presents the estimated hazard ratios for IPOs. The estimated coefficients for IPOs are presented in Table 9 in the Appendix. Column (i) of Table 6 shows the estimated results using the proportional hazards regression when RD, FLEX, E/TF, CAPEX, SIZE, MTB, SUB, and the entry cohort dummies are included in the model. Columns (ii), (iii), and (iv) show the estimated results using the competing risks regression, instead of the proportional hazards regression. As already mentioned, Holmström and Tirole (1993) argued that the fraction of firms going public increases with the amount of long-term capital. Column (iii) shows the effect of long-term capital on the time to IPO when LONG/TF, instead of EF/TF, is used. To identify the differences in IPOs between industries, column (iv) shows the estimated results using the industry dummies (I_MANU, I_ICT, and I_SERV), instead of MTB. Moreover, column (v) shows the estimated results with the time-variant covariate, JINDEX. ${ }^{20}$

As Table 6 shows, overall, we obtain rigorous results even when the alternative covariates or estimation methods are used. In Table 6, the hazard ratios of RD are more than one and statistically significant, indicating that start-up firms that engage in R\&D activities seek IPOs. Moreover, FLEX has a positive and significant effect on the time to IPO. ${ }^{21}$ The results of this study indicate that start-up firms that engage in innovative and uncertain businesses, such as high-tech start-ups, are more likely to go public earlier than others. Previous studies have argued that access to bank loans is difficult for firms with R\&D investment and equity financing has advantages over debt financing for R\&D investment (e.g., Carpenter and Petersen 2002a; Hall 2002; Colombo and Grilli 2007). We provide supportive evidence on H1, whereas some scholars emphasized the problem of loss of confidentiality for firms in hightech sectors (e.g., Campbell 1979; Yosha 1995; Pagano et al. 1998). The findings suggest that high-tech start-ups are expected to compensate for such uncertainty with growth potential through the IPO. In this respect, junior stock markets could provide opportunities for raising equity financing for start-up firms that engage in innovative businesses. The findings also suggest that early-stage shareholders'

\footnotetext{
20 We do not employ the competing risks regression when the time-invariant covariate is included. Moreover, taking into account the heterogeneity between the entry cohorts, we use the proportional hazards model with shared frailty based on the entry cohort years. As a result, we obtain similar results to those in Table 6.

21 We define a covariate for the ratio of capital surplus to total finance and estimate its effect on the time to IPO. As a result, its coefficient is positive at the $1 \%$ significance level. This indicates that start-up firms that raise equity financing through capital surplus are more likely to go public earlier than others.
} 


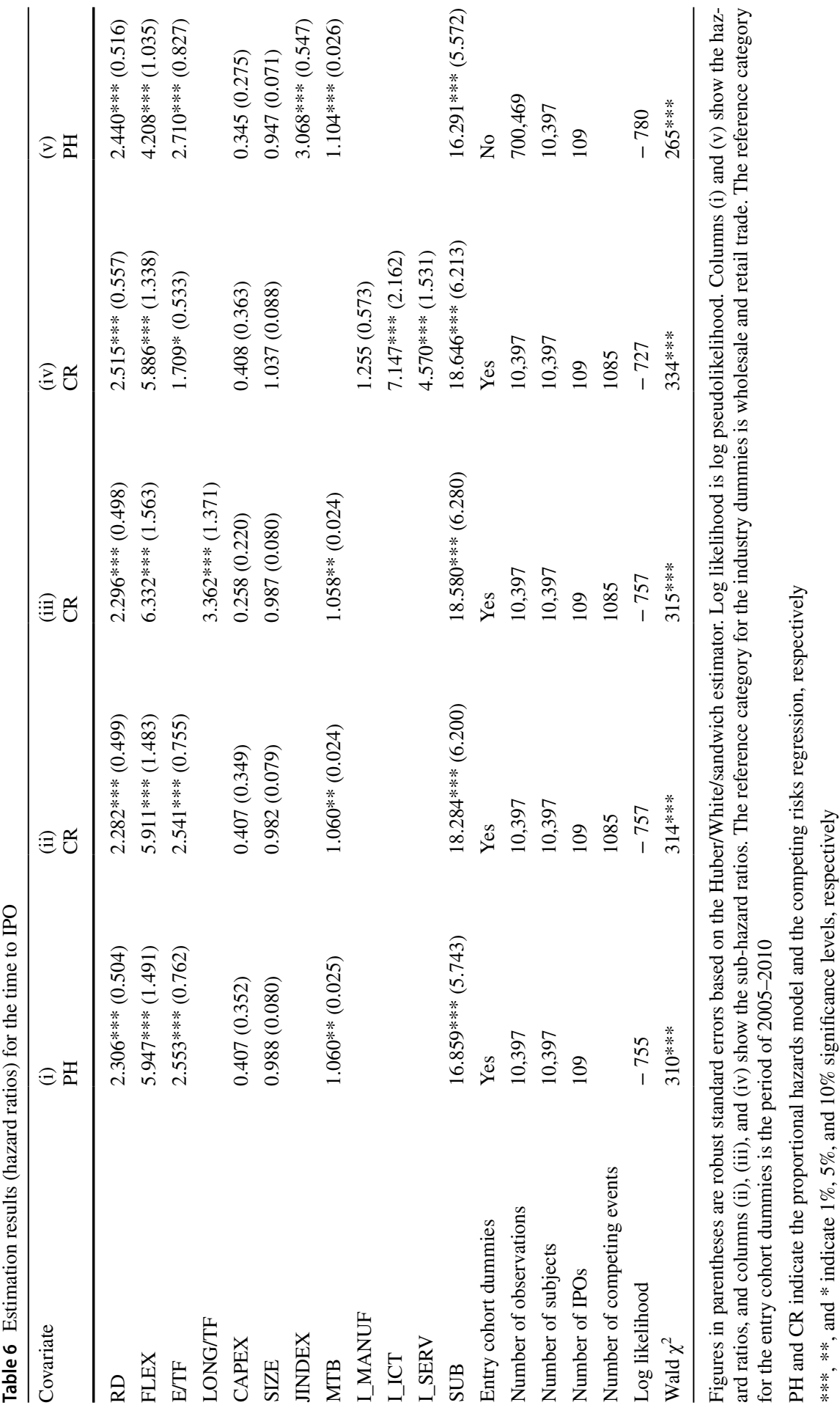


response to innovative and uncertain businesses in the demand for initial equity capital is significantly associated with the likelihood of an IPO.

With respect to initial capital structure, Table 6 shows that the hazard ratios of E/TF are more than one and statistically significant. This indicates that the likelihood of an IPO increases with the ratio of equity financing at founding, which is consistent with Cattaneo et al. (2015) who found that firm leverage has a negative on this likelihood. We provide evidence that start-up firms that rely heavily on equity financing, rather than on debt financing, are more likely to go public earlier than others. The results also suggest that some start-up firms that rely heavily on equity capital provided by early-stage shareholders, including entrepreneurs, tend to seek IPOs to access public equity markets. Early-stage shareholders who bear a large proportion of initial funds may have a strong incentive to go public early, partly because they can secure an opportunity to sell their highly risky shares. Moreover, the hazard ratios of LONG/TF are more than one and statistically significant in column (iii) of Table $6 .{ }^{22}$ We provide evidence that the likelihood of an IPO is positively associated with long-term capital, which is consistent with Holmström and Tirole (1993). This indicates that start-up firms that rely heavily on long-term capital are more likely to go public earlier than others.

Consequently, our results do not support the rebalance hypothesis (H2a) but do support the path dependence hypothesis (H2b). Our findings contradict those of Aslan and Kumar (2011) and De Jong et al. (2012). However, these studies examined the decision to go public, regardless of firm age, while our study focuses only on start-up firms. In this respect, the determinants of IPOs for start-up firms differ from those for established firms, suggesting that the effect of capital structure on the likelihood of an IPO depends on the growth process. In other words, incentives to go public may evolve over time. Whether start-up firms seek to expand equity financing-eventually, to conduct IPOs - may be affected by the inherent capital structure, since debt is likely to be a poor substitute for equity (Carpenter and Petersen 2002a). The financial strategies of start-up firms depend on their inherent capital structure, and path dependence may exist in the capital structure of start-up firms. Conversely, the results reveal that start-up firms that rely heavily on debt financing, such as bank loans, have less incentive to go public. In this respect, initial debt financing may trigger relationships with banks. The findings suggest that start-up firms that can rely on financial institutions, including main banks, at founding do not need to access public equity markets, presumably because financial institutions help provide capital to these firms.

Table 6 shows that the hazard ratios of MTB are more than one and statistically significant. We find a significant effect of the industry's market-to-book ratio on the IPO decision. We provide support for H3, which is consistent with Pagano et al. (1998), Aslan and Kumar (2011), and De Jong et al. (2012). The results indicate that growth opportunities have a significant impact on the likelihood of an IPO. Moreover, the industry dummies for I_ICT and I_SERV are higher than other industry

\footnotetext{
${ }^{22}$ We also estimate the effect of long-term debt ratio, measured by the ratio of long-term debt to total assets, on the time to IPO. As a result, the coefficient of the long-term debt ratio is negative but insignificant for the time to IPO.
} 
dummies. The results indicate that start-up firms in industries with higher marketto-book ratios, such as the ICT and service industries, are more likely to go public earlier than those in other industries. This indicates that start-up firms in the ICT industry-so-called "ICT ventures"-are more likely to go public earlier, in comparison to those in other industries. The results indicate that start-up firms tend to go public in growing industries because shareholders expect higher valuation in stock markets. These findings suggest that the likelihood of an IPO is affected not only by growth opportunities but also by stock market conditions.

In column (v) of Table 6, the hazard ratio of JINDEX is more than one and significant. This indicates that the IPO decision depends heavily on market conditions, such as hot and cold markets, and that the likelihood of an IPO increases as market conditions are more favorable, which provides support for H4. This finding is consistent with previous studies (e.g., Ibbotson and Jaffe 1975; Ritter 1984; Helwege and Liang 2004). As Pagano et al. (1998) argued, there is a positive relationship between the likelihood of an IPO and the stock market valuation of firms, and a boom may raise awareness of IPOs. The result reveals that the likelihood of an IPO is influenced by macroeconomic conditions that start-up firms face.

Regarding the controls, Table 6 shows that the hazard ratios of CAPEX are insignificant. Although De Jong et al. (2012) emphasized that growing and heavily investing firms seek to finance their growth with public equity capital, we find no evidence that start-up firms with high capital expenditures are more likely to go public earlier than others. The results indicate that initial capital expenditures are not associated with the likelihood of an IPO. Initial capital expenditures may not reflect the demand for access to public equity markets, partly because many start-up firms encounter financial constraints at founding. Rather, firms with higher initial capital expenditures might rely on bank loans due to the availability of collateral. Moreover, Table 6 shows that the hazard ratios of SIZE are insignificant. We find little evidence that larger firms at founding are more likely to go public earlier than others. ${ }^{23}$ Our findings are not consistent with Pagano et al. (1998), Chemmanur et al. (2010), De Jong et al. (2012), and Cattaneo et al. (2015). Furthermore, in Table 6, the hazard ratios of SUB are more than one and statistically significant. The results indicate that subsidies and affiliated firms tend to go public among start-up firms.

\subsection{Robustness check}

In the previous subsection, we presented the estimated results using the survival analysis approach, while taking into account the occurrence of a competing event alternative to an IPO. In the analysis, mergers were regarded as the competing event because, as discussed, M\&A is much less common as a strategic sellout in Japan. It is possible that some mergers are successful sellouts through the eventual sale of shares, although others show bailout mergers. Recently, Signori and Vismara (2018) examined the decision to go public relative to merger opportunity, and they argued that young and innovative firms expect potential merger synergies.

\footnotetext{
${ }^{23}$ When excluding the dummy for subsidies from the sample, we find a significant effect of initial firm size on the time to IPO.
} 


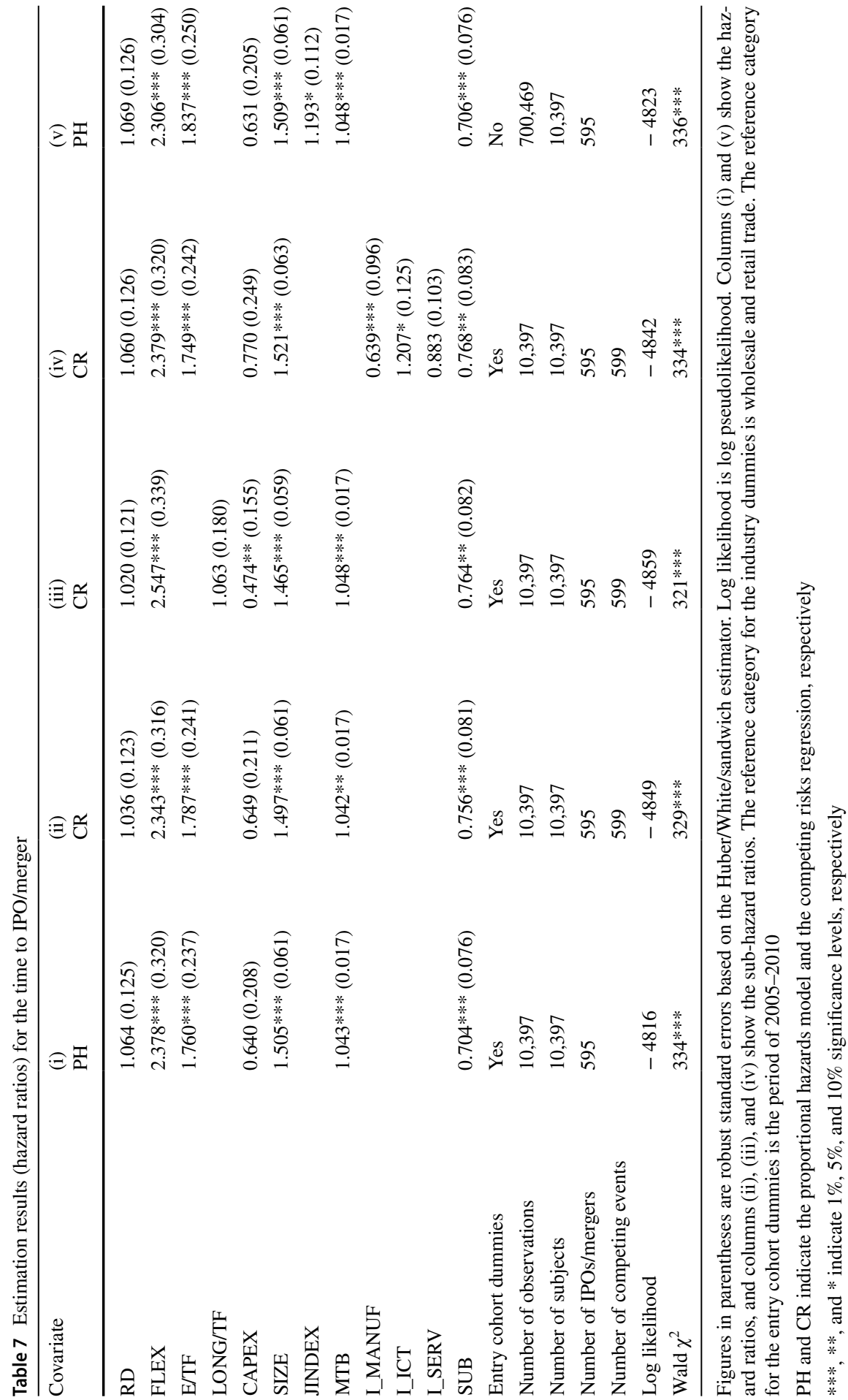


For the robustness check, we regard both IPOs and mergers as successful sellout strategies. In this case, there are 595 events of interest (109 IPOs plus 486 mergers) and 599 competing events (1085 exits minus 595 mergers). By doing so, we obtain more robust results for the sellout strategy of early-stage shareholders. In accordance with Table 6 , we present the estimated hazard ratios for the time to IPO/merger in Table 7. In addition, Tables 10 and 11 in the Appendix present the estimated hazard ratios for the time to merger and firm exit, respectively.

Regarding the time to IPO/merger, in Table 7, the hazard ratios of FLEX are more than one and statistically significant, indicating that start-up firms that engage in uncertain businesses, as measured by capital flexibility, are more likely to go public or merge earlier than others. In contrast, the hazard ratios of RD are insignificant in Table 7. We find no evidence that start-up firms that engage in R\&D activities are more likely to go public or merge earlier than others. This may suggest that acquirers do not feel much attraction towards start-up firms with innovative businesses, partly because they cannot easily reuse such investment, which tends to be firm specific. In addition, the hazard ratios of $\mathrm{E} / \mathrm{F}$ are more than one and statistically significant, and MTB has a positive effect on the time to IPO/merger. These results are consistent with the results for the time to IPO in Table 6. In contrast, in Table 7, the hazard ratios of SIZE are more than one and statistically significant, while those of SUB are less than one. The results reveal that large start-up firms, other than subsidiaries and affiliated firms, are more likely to go public or merge earlier than others. This indicates that early-stage shareholders of large independent firms tend to seek opportunities for sellouts through a merger. Furthermore, Table 7 shows that the hazard ratio of JINDEX is more than one, although at the $10 \%$ significance level. The results indicate that market conditions affect the likelihood of an IPO, rather than that of a merger, among start-up firms. Overall, while some similar results are found in Table 7, the effects of other covariates, such as R\&D activities and initial firm size, on the time to IPO/merger are different from those on the time to IPO in Table 6. This may indicate that mergers are essentially different from IPOs and include different purposes, such as bailout mergers. ${ }^{24}$

Furthermore, we examine whether the time to IPO varies depending on the type of start-up firms, innovative/uncertain businesses and others, to take into account the presence of cofounding factors affecting the choice of type. For this purpose, we estimate the treatment effects for observational survival-time data. Specifically, we estimate average treatment effects (ATEs), in addition to potential-outcome means (POMs), using inverse-probability-weighted regression adjustment (IPWRA) estimators. Table 8 presents the ATEs and POMs of innovative and uncertain businesses measured by the two proxies (RD and FLEX). In Table 8, we specify the outcome model as a function of E/F, MTB, and SUB, following a Weibull distribution; the treatment model as a function of CAPEX, MTB, and the industry dummies (I_MANU, I_ICT, and I_SERV) following a logistic distribution; and the censoring

\footnotetext{
${ }^{24}$ We present the estimation results for the time to merger and the time to firm exit in Tables 10 and 11 in the Appendix, respectively, following Honjo and Kato (2019) who examined the time to firm exit for start-up firms. As shown in these tables, the determinants of mergers tend to be similar to those of firm exits. In this respect, it is possible that mergers in Japan involve bailout mergers.
} 
model as a function of SIZE, the industry dummies, and the entry cohort dummies following a Weibull distribution. The findings in Table 8 are consistent with the argument that start-up firms that engage in innovative and uncertain businesses are more likely to go public earlier than others. On average, the time to IPO is estimated to be about 24-26 months less than when start-up firms do not engage in innovative and uncertain businesses.

\section{Conclusions}

This study has explored the IPOs of start-up firms in Japan. We examined the factors affecting the time to IPO, using a sample of more than 10,000 start-up firms (jointstock companies) in Japan. Specifically, we examined whether start-up firms that engage in innovative and uncertain businesses are more likely to go public earlier than others. We provided evidence that these firms are more likely to do so. This indicates that the likelihood of an IPO depends on the type of firms, such as hightech start-ups. The results also revealed that start-up firms that rely on equity financing at founding are more likely to go public earlier than others. Moreover, we find that start-up firms in highly valued industries, such as the ICT sector, are more likely to go public earlier than in other industries, and that the likelihood of an IPO among start-up firms depends on the market conditions.

This study has several limitations. First, we did not examine ownership structure due to the lack of information, in addition to entrepreneurs' personal attributes - that is, who owns the majority of shares. We could not also identify in the data source whether a firm's shares are transferred after founding. The availability of data on corporate ownership and control would provide more comprehensive evidence on the IPO process. Second, this study was based on initial conditions taken from financial statements in the first accounting year, and longitudinal data to trace changes in the capital structure might elaborate on our findings. For this purpose, panel data on financial statements are needed, but this could result in selection bias, as firms with inferior performance are unwilling to report financial statements before they go out of business. Third, we identified innovative and uncertain businesses using only data obtainable from financial statements. Using a different measure, such as patents granted or new products, would be useful in future research. Fourth, the proportion of IPOs with a short period of time may be considerably low. We may have targeted specific sectors, such as ICT and biotechnology, following the previous studies (e.g., Vismara 2014; Honjo and Nagaoka 2018). Finally, we were unable to identify whether each merger is successful using the data source.

Despite these limitations, this study provides new insights into how the decision to go public is articulated in the literature. While previous studies on corporate finance have examined the decision to go public, they did not fully provide evidence on the determinants of IPOs among start-up firms; this was because their samples included privately held firms with long histories (e.g., Pagano et al. 1998; De Jong et al. 2012). Thus, previous studies have not sufficiently described the IPO process in the financial growth cycle of firms, and there is a paucity of empirical evidence on IPO decisions among start-up firms. Therefore, by focusing on start-up firms, 
Table 8 Treatment-effects estimators for the time to IPO: innovative and uncertain businesses

\begin{tabular}{llllll}
\hline Covariate & Coef. & SE & $|z|$ & $\begin{array}{l}\text { 95\% conf. } \\
\text { interval }\end{array}$ \\
\hline RD & & & & & \\
ATE & -23.7 & 7.16 & $3.31 * * *$ & -37.7 & -9.67 \\
POM & 64.7 & 6.84 & $9.46 * * *$ & 51.3 & 78.1 \\
FLEX & & & & & \\
ATE & -25.5 & 9.47 & $2.70 * * *$ & -44.1 & -6.97 \\
POM & 66.7 & 7.49 & $8.90^{* * *}$ & 52.0 & 81.4 \\
\hline
\end{tabular}

All figures are measured by the number of months. The IPWRA estimator is used. The outcome model is a function of E/F, MTB, and SUB following a Weibull distribution. The treatment model is a function of CAPEX, MTB, and the industry dummies (I_MANU, I_ICT, and I_SERV) following a logistic distribution. The censoring model is a function of SIZE, the industry dummies, and the entry cohort dummies following a Weibull distribution. The number of observations is 10,397

SE indicates robust standard errors; ATE indicates average treatment effects; POM indicates potential-outcome means

*** indicates $1 \%$ significance level

we contribute to the literature on the determinants of an IPO. This study shed some light on the growth process from the founding of a firm to its IPO, which could provide valuable insights into the financial growth cycle of firms and create a link between entrepreneurship and corporate finance, including management studies. In practice, the findings of this study indicate that initial conditions, such as capital structure, affect the likelihood of an IPO. This study provides support for the path dependence hypothesis, and the findings of the study indicate that the extension of equity financing at the time of founding leads to a future IPO. Geroski et al. (2010) suggested that research on the effects of initial conditions on the post-entry performance of firms has implications for entrepreneurs and policymakers. For entrepreneurs, these effects suggest that a great deal of care should be taken in preparing for the founding of firms. For policymakers, these effects suggest that financial support to foster start-up firms with growth potential—especially young IPO firms-would be needed depending on the circumstances of their birth. The extension of equity financing at the time of founding leads to a future IPO, and the inherent characteristics of firms may determine the likelihood of an IPO. In this sense, path dependence in financing can be observed in the growth cycle of firms. Initial conditions may determine the fate of start-up firms, just as a gene determines an individual's traits and characteristics in biology.

Moreover, this study provides further policy implications. The type of start-up firms that go public early would be of interest not only to entrepreneurs but also to investors, including venture capitalists and business angels, who look to IPOs to diversify their investment portfolios. In particular, young IPO firms often attract policymakers because they are expected to stimulate future economic growth. To provide equity financing-more precisely, opportunities to access public equity markets-for innovative and risky start-ups, junior stock markets have been introduced 
in some countries, including Japan. The findings of this study suggest that start-up firms operating in R\&D projects, including uncertain businesses, are more likely to go public early. We could support the existence of junior stock markets for innovative and risky start-ups, using the case of the Japanese IPOs. This may indicate that an IPO is a precious path to get access to equity financing for these firms even in countries, such as Japan, that have a bank-centered capital market with underdeveloped private equity capital. Rather, innovative and risky start-ups may have nothing but access to public equity markets through an IPO to secure external financing in these countries. By going public in junior stock markets, these firms have the future opportunity to access the main markets. Although the results are peculiar to Japanese industries, this analysis may be replicated in other countries that pursue policies of pushing start-up firms to go public. Further studies using the case of IPOs in other countries would provide greater insights into how to promote young and innovative firms with growth potential in the financial systems deeply rooted in the countries. Meanwhile, our findings suggest that the likelihood of an IPO depends on market conditions. When market conditions are unfavorable, the sellout strategy of early-stage shareholders through M\&A is necessary for start-up firms with growth potential. In this respect, the development of private equity capital, including bridge financing to IPO, appears necessary for the promotion of start-up firms with growth potential. This would warrant further research on the financial growth cycle of firms.

Acknowledgements This study was supported by the Japan Society for the Promotion of Science (JSPS) (Grant-in-Aid for Scientific Research, JP17K03713). The author would like to thank attendees at the 5th Asia-Pacific Innovation Conference held in the University of Technology, Sydney, and at the workshop held in Kwansei Gakuin University (Osaka Umeda Campus) for their useful comments and suggestions. A very preliminary version of this paper was presented at the Japanese Economic Association Autumn Meeting held in Kyushu Sangyo University. In particular, the author is grateful to Masatoshi Kato, Kenji Kutsuna, Daisuke Miyakawa, Kazuo Ogawa, Hirokyuki Okamuro, Jungwook Shim, Hidenori Takahashi, Yoji Takahashi, Miho Takizawa, Hirofumi Uchida, and Kazuo Yamada for their valuable comments and suggestions. The author is also grateful to the reviewer for insightful comments and suggestions. Any errors remaining are the author's own.

Open Access This article is licensed under a Creative Commons Attribution 4.0 International License, which permits use, sharing, adaptation, distribution and reproduction in any medium or format, as long as you give appropriate credit to the original author(s) and the source, provide a link to the Creative Commons licence, and indicate if changes were made. The images or other third party material in this article are included in the article's Creative Commons licence, unless indicated otherwise in a credit line to the material. If material is not included in the article's Creative Commons licence and your intended use is not permitted by statutory regulation or exceeds the permitted use, you will need to obtain permission directly from the copyright holder. To view a copy of this licence, visit http://creativecommons.org/licen ses/by/4.0/.

\section{Appendix}

Table 9 presents the estimated coefficients for the time to IPO. Tables 10 and 11 present the estimated hazard ratios for the time to merger and the time to firm exit, respectively. In Tables 10 and 11, an IPO is regarded as a survival during the observation window. 


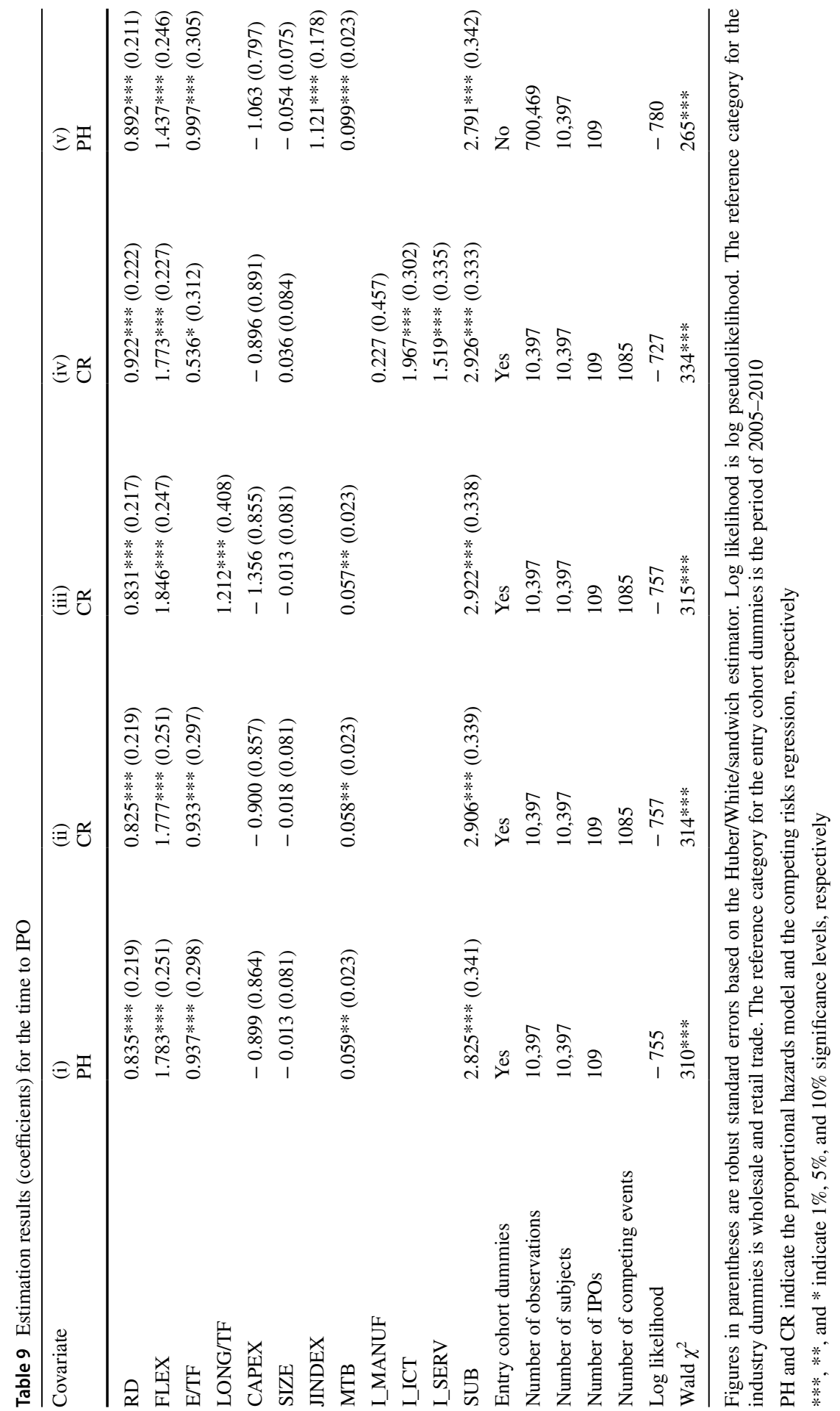




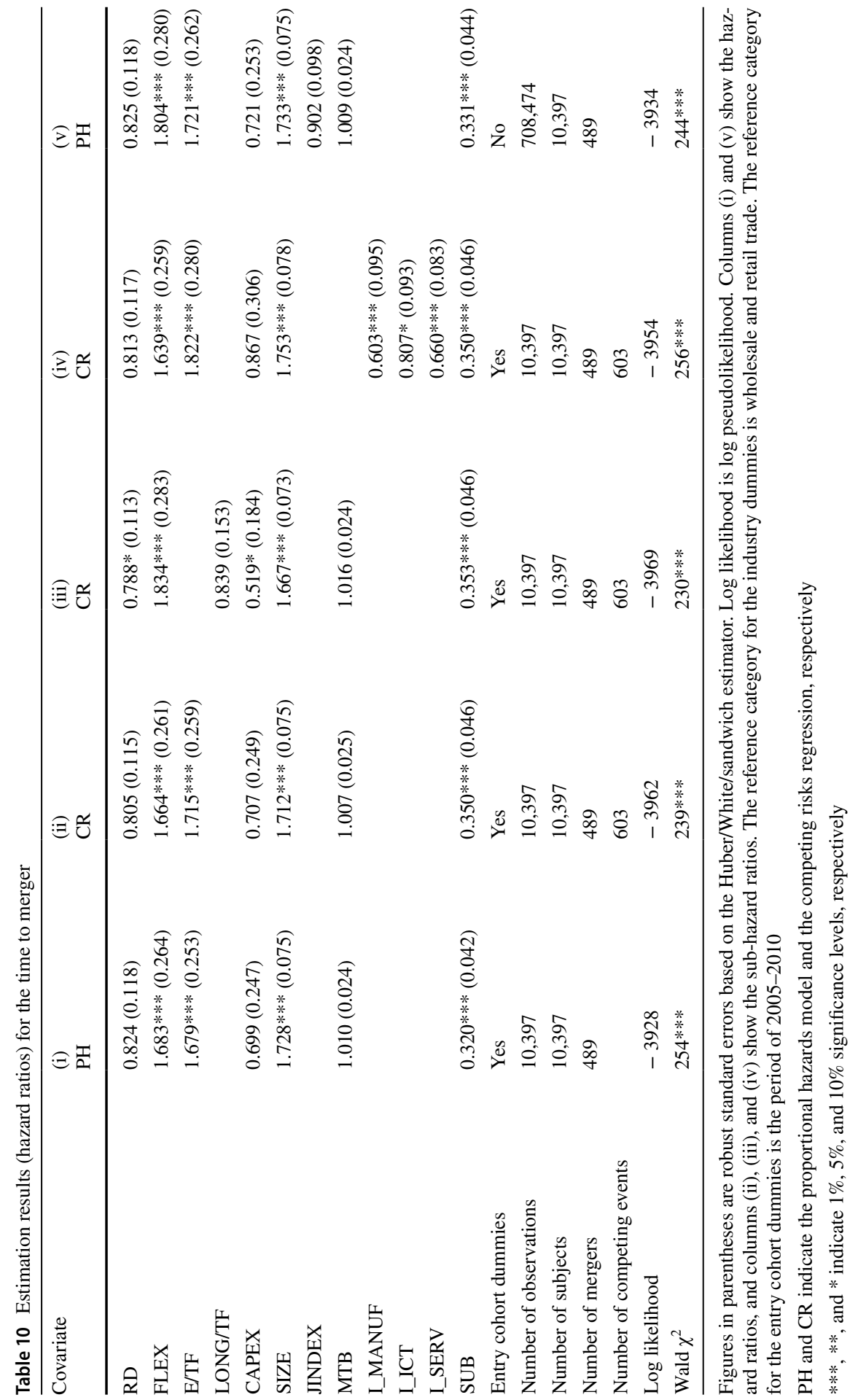


Table 11 Estimation results (hazard ratios) for the time to firm exit

\begin{tabular}{lllll}
\hline Covariate & (i) & (ii) & (iii) & (iv) \\
& PH & PH & PH & PH \\
\hline RD & $1.046(0.094)$ & $1.042(0.093)$ & $1.049(0.094)$ & $1.053(0.095)$ \\
FLEX & $1.557^{* * *}(0.184)$ & $1.587^{* * *}(0.186)$ & $1.546^{* * *}(0.184)$ & $1.696^{* * *}(0.199)$ \\
E/TF & $1.112(0.108)$ & & $1.172(0.117)$ & $1.144(0.111)$ \\
LONG/TF & & $0.973(0.121)$ & & \\
CAPEX & $0.702(0.152)$ & $0.663^{*}(0.140)$ & $0.787(0.172)$ & $0.720(0.156)$ \\
SIZE & $1.418^{* * *}(0.040)$ & $1.410^{* * *}(0.039)$ & $1.440^{* * *}(0.041)$ & $1.419^{* * *}(0.040)$ \\
JINDEX & & & & $0.801 * * *(0.060)$ \\
MTB & $1.007(0.016)$ & $1.009(0.016)$ & & $1.003(0.016)$ \\
I_MANUF & & & $0.767 * *(0.081)$ & \\
I_ICT & & & $0.843 * *(0.068)$ & \\
I_SERV & & & $0.777^{* * *}(0.064)$ & \\
SUB & $0.300^{* * *}(0.028)$ & $0.300^{* * *}(0.028)$ & $0.298^{* * *}(0.027)$ & $0.310^{* * * *}(0.029)$ \\
Entry cohort dummies & Yes & Yes & Yes & No \\
Number of observations & 10,397 & 10,397 & 10,397 & 708,474 \\
Number of subjects & 10,397 & 10,397 & 10,397 & 10,397 \\
Number of firm exits & 1092 & 1092 & 1092 & 1092 \\
Log likelihood & -8807 & -8807 & -8800 & -8820 \\
Wald $\chi^{2}$ & $314 * * *$ & $313^{* * *}$ & $320^{* * *}$ & $293 * * *$ \\
\hline
\end{tabular}

Figures in parentheses are robust standard errors based on the Huber/White/sandwich estimator. Log likelihood is log pseudolikelihood. The reference category for the industry dummies is wholesale and retail trade. The reference category for the entry cohort dummies is the period of 2009-2010

PH indicates the proportional hazards model

$* * *, * *$, and $*$ indicate $1 \%, 5 \%$, and $10 \%$ significance levels, respectively

\section{References}

Aalen OO (1978) Nonparametric inference for a family of counting processes. Ann Stat 6:701-726

Akyol AC, Cooper T, Meoli M, Vismara S (2014) Do regulatory changes affect the underpricing of European IPOs? J Bank Finance 45:43-58

Arrfelt M, Mannor M, Nahrgang JD, Christensen AL (2018) All risk-taking is not the same: examining the competing effects of firm risk-taking with meta-analysis. Rev Manag Sci 12:621-660

Arrow KJ (1962) Economic welfare and the allocation of resources for innovation. In: Nelson RR (ed) The rate and direction of inventive activity: economic and social factors. Princeton University Press, Princeton, pp 609-625

Aslan H, Kumar P (2011) Lemons or cherries? Growth opportunities and market temptations in going public and private. J Financ Quant Anal 46:489-526

Aspelunda A, Berg-Utbya T, Skjevdal R (2005) Initial resources' influence on new venture survival: a longitudinal study of new technology-based firms. Technovation 25:1337-1347

Audretsch DB (1995) Innovation and industry evolution. MIT Press, Cambridge

Audretsch DB, Acs ZJ (eds) (2003) Handbook of entrepreneurship research. Kluwer Academic, Boston

Audretsch DB, Bönte W, Keilbach M (2008) Entrepreneurship capital and its impact on knowledge diffusion and economic performance. J Bus Ventur 23:687-698

Audretsch DB, Lehmann EE (2013) Corporate governance in newly listed companies. In: Levis M, Vismara S (eds) Handbook of research on IPOs. Edward Elgar Publishing, Cheltenham, pp 552-567 
Audretsch DB, Mahmood T (1995) New firm survival: new results using a hazard function. Rev Econ Stat 60:441-450

Bade M (2018) Determinants of IPO-firms' merger appetite. Rev Manag Sci. https://doi.org/10.1007/ s11846-018-0291-2

Bayar O, Chemmanur TJ (2011) IPOs versus acquisitions and the valuation premium puzzle: a theory of exit choice by entrepreneurs and venture capitalists. J Financ Quant Anal 46:1755-1793

Berger AN, Udell GF (1995) Relationship lending and lines of credit in small firm finance. J Bus 68:351-381

Berger AN, Udell GF (1998) The economies of small business finance the roles of private equity and debt markets in the financial growth cycle. J Bank Finance 22:613-673

Bertoni F, Colombo MG, Quas A (2015) The patterns of venture capital investment in Europe. Small Bus Econ 45:543-560

Bhamra HS, Kuehn L-A, Strebulaev IA (2010) The aggregate dynamics of capital structure and macroeconomic risk. Rev Financ Stud 23:4187-4241

Binks MR, Ennew CT (1996) Growing firms and the credit constraint. Small Bus Econ 8:17-25

Binks MR, Ennew CT, Reed GV (1992) Information asymmetries and the provision of finance to small firms. Int Small Bus J 11:35-46

Black BS, Gilson RJ (1998) Venture capital and the structure of capital markets: banks versus stock markets. J Financ Econ 47:243-277

Block JH, Colombo MG, Cumming DJ, Vismara S (2018) New players in entrepreneurial finance and why they are there. Small Bus Econ 50:239-250

Bodnaruk A, Kandel E, Massa M, Simonov A (2008) Shareholder diversification and the decision to go public. Rev Financ Stud 21:2779-2824

Brau JC, Fawcett SE (2006) Initial public offerings: an analysis of theory and practice. J Finance 61:399-436

Brau JC, Francis B, Kohers N (2003) The choice of IPO versus takeover: empirical evidence. J Bus 76:583-612

Campbell TS (1979) Optimal investment financing decisions and the value of confidentiality. J Financ Quant Anal 14:913-924

Carpenter RE, Petersen BC (2002a) Capital market imperfections, high-tech investment, and new equity financing. Econ J 112:F54-F72

Carpenter RE, Petersen BC (2002b) Is the growth of small firms constrained by internal finance? Rev Econ Stat 84:298-309

Cattaneo M, Meoli M, Vismara S (2015) Financial regulation and IPOs: evidence from the history of the Italian stock market. J Corp Finance 31:116-131

Chemmanur TJ, He S, Nandy DK (2010) The going-public decision and the product market. Rev Financ Stud 23:1855-1908

Colombo MG, Cumming DJ, Vismara S (2016) Governmental venture capital for innovative young firms. J Technol Transf 41:10-24

Colombo MG, Grilli L (2007) Funding gaps? Access to bank loans by high-tech start-ups. Small Bus Econ 29:25-46

Cooper AC, Gimeno-Gascon FJ, Woo CY (1994) Initial human and financial capital as predictors of new venture performance. J Bus Ventur 9:371-395

Cox DR (1972) Regression models and life-tables (with discussion). J R Stat Soc B 34:187-220

Czarnitzki D, Hottenrott H (2011) R\&D investment and financing constraints of small and medium-sized firms. Small Bus Econ 36:65-83

De Jong A, Huijgen CA, Marra TA, Roosenboom P (2012) Why do firms go public? The role of the product market. J Bus Finance Acc 39:165-192

Fine JP, Gray RJ (1999) A proportional hazards model for the subdistribution of a competing risk. J Am Stat Assn 94:496-509

Gans JS, Hsu DH, Stern S (2002) When does start-up innovation spur the gale of creative destruction? Rand J Econ 33:571-586

Gao X, Ritter JR, Zhu Z (2013) Where have all the IPOs gone? J Financ Quant Anal 48:1663-1692

Gerakos J, Lang M, Maffett M (2013) Post-listing performance and private sector regulation: the experience of London's Alternative Investment Market. J Acc Econ 56:189-215

Geroski PA, Mata J, Portugal P (2010) Founding conditions and the survival of new firms. Strateg Manag J 31:510-529 
Giot P, Schwienbacher A (2007) IPOs, trade sales and liquidations: modelling venture capital exits using survival analysis. J Bank Finance 31:679-702

Granier C, Revest V, Sapio A (2019) SMEs and junior stock markets: a comparison between European and Japanese markets. J Innov Econ Manag 29:43-67

Gray RJ (1988) A class of k-sample tests for comparing the cumulative incidence of a competing risk. Ann Stat 16:1141-1154

Hall BH (2002) The financing of research and development. Oxf Rev Econ Policy 18:35-51

Harhoff D, Stahl K, Woywode M (1998) Legal form, growth and exit of West German firms-empirical results for manufacturing. J Ind Econ 46:453-488

Helm R, Mauroner O (2007) Success of research-based spin-offs. State-of-the-art and guidelines for further research. Rev Manag Sci 1:237-270

Helwege J, Liang N (2004) Initial public offerings in hot and cold markets. J Financ Quant Anal 39:541-569

Henrekson M, Johansson D (2010) Gazelles as job creators: a survey and interpretation of the evidence. Small Bus Econ 35:227-244

Himmelberg CP, Petersen BC (1994) R\&D and internal finance: a panel study of small firms in high-tech industries. Rev Econ Stat 76:38-51

Holmström B, Tirole J (1993) Market liquidity and performance monitoring. J Polit Econ 101:678-709

Honjo Y (2001) Do innovative start-ups really wish to go public? Evidence from Japanese electrical manufacturing companies. Appl Econ Lett 8:493-497

Honjo Y (2015) Why are entrepreneurship levels so low in Japan? Jpn World Econ 36:88-101

Honjo Y, Kato M (2019) Do initial financial conditions determine the exit routes of start-up firms? J Evol Econ 29:1119-1147

Honjo Y, Kato M, Okamuro H (2014) R\&D investment of start-up firms: does founders' human capital matter? Small Bus Econ 42:207-220

Honjo Y, Kutsuna K (2010) An empirical analysis of the initial public offering intention: evidence from start-up firms in Japan. Corp Owner Contr 7:127-141

Honjo Y, Nagaoka S (2018) Initial public offering and financing of biotechnology start-ups: evidence from Japan. Res Policy 47:180-193

Huyghebaert N, Van de Gucht L, Van Hulle C (2007) The choice between bank debt and trade credit in business start-ups. Small Bus Econ 29:435-452

Ibbotson R, Jaffe J (1975) Hot issue markets. J. Finance 30:1027-1042

Kamien MI, Schwartz NL (1978) Self-financing of an R and D project. Am Econ Rev 68:252-261

Koski H, Pajarinen M (2013) The role of business subsidies in job creation of start-ups, gazelles and incumbents. Small Bus Econ 41:195-214

Lerner J (1994) Venture capitalists and the decision to go public. J Financ Econ 35:293-316

Mata J, Portugal P (1994) Life duration of new firms. J Ind Econ 42:227-245

Mata J, Portugal P, Guimarães P (1995) The survival of new plants: start-up conditions and post-entry evolution. Int J Ind Organ 13:413-614

Matsuda S, Vanderwerf P, Scarbrough P (1994) A comparison of Japanese and U.S. firms completing initial public offerings. J Bus Ventur 9:205-222

Müller E, Zimmermann V (2009) The importance of equity finance for R\&D activity. Small Bus Econ 33:303-318

Nelson W (1972) Theory and applications of hazard plotting for censored failure data. Technometrics 14:945-966

Pagano M, Panetta F, Zingales L (1998) Why do companies go public? An empirical analysis. J Finance 53:27-64

Petersen MA, Rajan RG (1994) The benefits of lending relationships: evidence from small business data. J Finance 49:3-37

Poulsen AB, Stegemoller M (2008) Moving from private to public ownership: selling out to public firms versus initial public offerings. Financ Manag 37:81-101

Puri M, Zarutskie R (2012) On the life cycle dynamics of venture-capital- and non-venture-capitalfinanced firms. J Finance 67:2247-2293

Rajan RG (1992) Insiders and outsiders: the choice between informed and arm's-length debt. J Finance 47:1367-1400

Ritter JR (1984) The "hot issue" market of 1980. J Bus 57:215-240

Ritter JR, Signori A, Vismara S (2013) Economies of scope and IPO activity in Europe. In: Levis M, Vismara S (eds) Handbook of research on IPOs. Edward Elgar Publishing, Cheltenham, pp 11-34 
Ritter JR, Welch I (2002) A review of IPO activity, pricing, and allocations. J Finance 62:1759-1828

Röell A (1996) The decision to go public: an overview. Eur Econ Rev 40:1071-1081

Signori A, Vismara S (2018) M\&A synergies and trends in IPOs. Technol Forecast Soc Change 127:141-153

Small and Medium Enterprise Agency (2009) White paper on small and medium enterprise in Japan, 2009. Japan Small Business Research Institute, Tokyo

Takahashi H (2018) Affiliation ties and underwriter selection. Small Bus Econ 50:325-338

Takahashi H, Yamada K (2015) IPOs, growth, and the impact of relaxing listing requirements. J Bank Finance 59:505-519

Venture Enterprise Center (2015) VEC Yearbook 2015: annual report on Japanese Startup business 2018. Venture Enterprise Center, Tokyo

Vismara S (2014) Patents, R\&D investments and post-IPO strategies. Rev Manag Sci 8:419-435

Vismara S, Paleari S, Ritter JR (2012) Europe's second markets for small companies. Eur Financ Manag $18: 352-388$

Yamada K (2013) How bank health affects the capital structure and performance of IPO firms: evidence from the Japanese financial crisis in the 1990s. In: Levis M, Vismara S (eds) Handbook of research on IPOs. Edward Elgar Publishing, Cheltenham, pp 552-567

Yosha O (1995) Information disclosure costs and the choice of financing source. J Financ Intermed 4:3-20

Zingales L (1995) Insider ownership and the decision to go public. Rev Econ Stud 62:425-448

Publisher's Note Springer Nature remains neutral with regard to jurisdictional claims in published maps and institutional affiliations. 